\section{La construcción de iglesias en Alemania durante los siglos XX y XXI}

En busca de una casa para Dios y para el hombre Church-building in Germany during the 20th and 21st centuries

In Search of a House for God and Men

WALTER ZAHNER

https://doi.org/10.17979/aarc.2007.1.0.5017

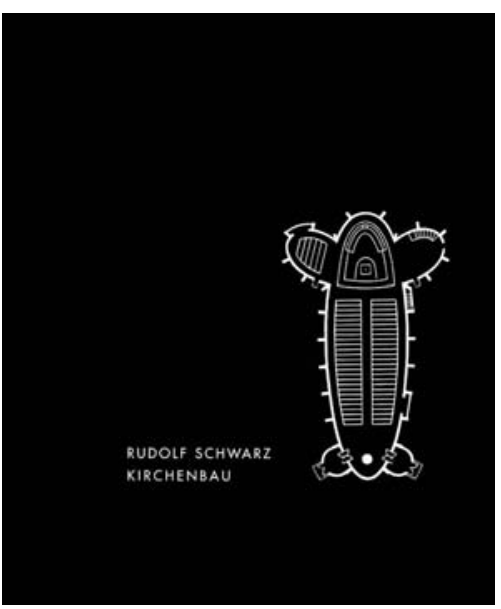

Rudolf Schwarz, portada del libro Kichenbau, 1960.

\section{Introduction}

It is some kind of a phenomenon. Fewer churches are being built in the last 25 years in Germany, as well as in the whole Central Europe and a great part of Southern Europe. However, the discussion around church-building has never stopped, rather, it has thrived. This is probably due to several reasons.

The German literary market saw a few weeks ago the new edition of a book first released 47 years ago: "Kirchenbau. Welt vor der Schwelle» (Church-building. The World before the Threshold) ${ }^{1}$. The publishing house is promoting it by saying that the seminal book by the famous architect Rudolf Schwarz is available once again.

Undoubtedly, Rudolf Schwarz (1897-1961) can be defined as one of the most relevant German church architects in the past century ${ }^{2}$, and not just because he has built over 40 churches, but because, unlike most of his colleagues, he has written a great number of books. All of the most important ones have been published again. The book «Vom Bau der Kirche» (On ChurchBuilding), just to quote one example, was released in 1938 and 1947, and then published for a third time in 1998, being now completely out of print ${ }^{3}$. It was translated into Italian for the first time a few years ago.

This is amazing because, "Church-building. The World before the Threshold» contains a rather 
complicated discourse. Both Romano Guardini ("this book needs an introduction. It is based on a new and infrequent point of view» ${ }^{4}$ ) and Ludwig Mies van der Rohe ("his book is not an easy read, in spite of its clarity ${ }^{5}$ ) had already noted it in their respective prologues.

According to the words of the architect's widow in the preface to the latest edition, the book can and should be able to convey nowadays «the requirement of a kind of spirituality contained in spaces which builds a world opposed to the disposable society oriented towards postmodern consumerism ${ }^{6}$. The Bonn liturgical scientist Albert Gerhards mentions something less prosaic but similar in his message about Schwarz: "The spiritual ambition of his constructions poses an on-going question, referred both to the theory and the praxis of the liturgy and to the believers' selfcomprehension as community (...) Somehow, he is acknowledged as a role model for churchbuilding projects» ${ }^{7}$.

But just before quoting examples of religious architecture in Germany, let me point out some theological thoughts in this regard. What is a church? Which elements integrate it? What is the thing that determines it?

The early Christians did not require a specific place for their gatherings. They would assemble at the synagogue or in private homes, also inside the catacombs. The Church is made of «live stones» ${ }^{8}$. Primitive writings describe how they would gather in order to distribute bread and wine (Facts 2, 42-47; cf. also Didache), just like Jesus did with his Apostles during the Last Supper (Matthew 26, 20-29 and synoptic). The core event was this meeting, the centre of life and faith, since they were gathered under the symbols of bread and wine, united in faith and hope and strengthened by the joint experience.

With it, the primitive Christian community was established as the successors of the one who is «Bread of Life» (John 3, 48) and the chalice offered constitutes "the Chalice of the New Alliance» (1 Corinthians 11, 25 following; Luke 22, 20). With this New Alliance, they are all part of Christ's Body (1 Corinthians 10, 17), and they are not just a part, they are «chosen lineage, royal priesthood, holy nation, people acquired by God» (1 Peter 2, 9).

During the first two centuries, there is no evidence that Christian communities built places for their meetings. Hoping the Crucified one would soon return, the first generations did not require a final place. Paul says as follows: «Don't you know that you are God's temple and that God's spirit lives in you? If somebody destroys God's temple, God shall destroy him libro no es fácil de leer, a pesar de su claridad» ${ }^{5}$ ) ya lo habían hecho notar expresamente en sus prólogos respectivos.

Tal como dice la viuda del arquitecto en el prefacio de la última edición, el libro debe y puede transmitir también hoy «la exigencia de una espiritualidad contenida en espacios, que construye un mundo contrario a la sociedad de usar y tirar orientada al consumismo de la postmodernidad ${ }^{6}$. Algo menos prosaico pero parecido en su mensaje dice el científico litúrgico de Bonn Albert Gerhards, refiriéndose a Schwarz: «La ambición espiritual de sus construcciones plantea una continua pregunta, referida tanto a la teoría y la praxis de la liturgia como a la autocomprensión de los fieles en cuanto comunidad (...) De alguna manera, se le reconoce como ejemplo para nuevos proyectos en la construcción de iglesias» ${ }^{7}$.

Pero antes de mencionar ejemplos de la arquitectura religiosa en Alemania quiero adelantar algunos pensamientos teológicos al respecto. ¿Qué es una iglesia? ¿Qué cosas la componen? ¿Qué la determina?

Los primeros cristianos no necesitaban de un lugar especial para sus reuniones. Ellos se reunían en las sinagogas o en sus casas particulares; posteriormente, también en las catacumbas. Las Iglesia se compone de piedras vivas ${ }^{8}$. Los primitivos escritos describen cómo se reunían para partir el pan y repartir el vino (Hch 2, 42-47; cf. también Didache), como lo hizo Jesús con los suyos, los Apóstoles, en la Última Cena (Mt 26, 20-29 y sinópticos). El acontecimiento central, el centro de la vida y de la fe, era esta reunión, porque bajo los signos del pan y del vino, que le representaban a Él, estaban unidos en la fe, en la esperanza y fortalecidos en la experiencia común.

Con ella, la primitiva comunidad cristiana se constituía como sucesora de Aquél que es el «Pan de la Vida» (Jn 3, 48) y el Cáliz que se ofrece, formando el «Cáliz de la Nueva Alianza» (1 Cor 11, $25 \mathrm{ss}$; Lc 22, 20). Con esta Nueva Alianza, todos son parte del Cuerpo de Cristo (1 Cor 10,17), y no solamente tienen parte, sino que son «linaje escogido, sacerdocio real, nación santa, pueblo adquirido por Dios» (1 Pe 2, 9).

Durante los dos primeros siglos, no tenemos constancia de que las comunidades cristianas edificasen lugares para sus reuniones. En la esperanza de que el Crucificado iba a volver pronto, las primeras generaciones no necesitaron un lugar definitivo. Ellos se sentían resguardados en Él. Pablo lo dice de la siguiente manera: «¿No sabéis que sois templo de Dios y que el Espíritu de Dios habita en vosotros? Si alguno destruye el templo de Dios, Dios lo destruirá a él, porque el templo de Dios es santo, y eso es lo que vosotros sois» $(1$ Cor 3,16$)$. De manera que el templo, su presencia, no era ninguna construcción de simples piedras, sino una construcción de piedras vivas (1 Pe 2, 5).

Albert Gerhards dice: «Como la presencia de Dios se ha unido a una persona - la de la Palabra hecha carne - no existen lugares especiales de la presencia de Dios, sino los de la comunidad reunida en nombre de Jesucristo». Por eso pudieron decir los primeros apologetas cristianos, en contraste con las prácticas de culto paganas, que «los cristianos no tienen ni altar, ni templo, ni ofrenda» ${ }^{9}$. 
Sólo cuando los creyentes tuvieron claro que Él, el Señor, no volvería enseguida, y viendo que el número de cristianos crecía continuamente, se decidieron a organizar iglesias en sus casas, y más tarde, incluso a construirlas. La iglesia más antigua que se conoce está en Dura Europos, en el Eufrates. La casa, construida durante el siglo I, se remodeló durante la primera mitad del siglo III como Domus ecclesia, con una gran nave, así como con un baptisterio propio.

Después del reconocimiento oficial del cristianismo por el emperador Constantino, en el año 313, se construyeron las primeras iglesias propiamente dichas, que se parecían a las basílicas romanas; y enseguida hubo una iglesia en cada ciudad que, a la vez, servía como sede del Obispo (catedral). Durante los siglos posteriores, múltiples factores influyeron en los estilos de construcción de las iglesias: no sólo las ideas teológicas, sino también las corrientes espirituales y terrenales, lo que hizo que su estructura arquitectónica cambiara. A las iglesias románicas les siguen las catedrales góticas, que se entienden como ciudades de Dios en la tierra. Las construcciones renacentistas fueron suplantadas por las salas regias del Barroco ${ }^{10}$, y durante el siglo XIX encontramos un renacer de los estilos antiguos: el llamado Historicismo ${ }^{11}$.

¿Qué son las iglesias, a las que vemos como testimonios de piedra de la fe cristiana $^{12}$ para el hombre del siglo XXI? Las iglesias son:

- Lugares santos. En primer lugar, sirven para celebrar la liturgia, o lo que es lo mismo, están construidas según sus necesidades. Mediante la consagración del templo, éste se convierte en un lugar especial «donde se reúne la comunidad cristiana para escuchar la Palabra de Dios, rezar unidos, celebrar la eucaristía y los demás sacramentos. Son, de una forma especial, signo de la Iglesia peregrina en la tierra y son, a su vez, imagen de la Iglesia que ya está en el cielo» ${ }^{13}$.

- Lugares para celebraciones religiosas diversas. Al margen de la expresión máxima de la liturgia cristiana — la celebración de la eucaristía-, también ofrecen, y muy especialmente, sitio y espacio para muchas otras celebraciones, como las de los demás sacramentos y formas sacramentales, la celebración de la palabra de Dios, oficios religiosos, procesiones, etc.

- Lugares para la piedad individual. En la mayor parte de las iglesias existen diferentes espacios - o parte de ellos- para la oración personal. Las iglesias son lugares para el retiro, lugares para rezar, para la meditación personal o para la veneración de los santos.

Es decir, las iglesias son los lugares que acogen las diversas formas de manifestación de la fe ${ }^{14}$. Están situadas en lugares destacados, tanto en lo referente a la estructura de la ciudad como en sentido teológico, ya que las iglesias marcan los emplazamientos donde están enterrados santos o personas que han tenido una importancia especial, cementerios o lugares donde ocurrieron acontecimientos milagrosos, y que han sido venerados durante años o incluso siglos.

Además de esto, las iglesias también son lugares que ejercen su influencia en la sociedad, ya que a través de su simple presencia manifiestan que because God's temple is holy and that is what you are» (1 Corinthians 3, 16). Thus, the temple, his presence, was not a building of simple stones, but a building of live stones (1 Peter 2, 5).

Albert Gerhards says: «Since God's presence has been linked to one person - the embodied Word - there are no special places for God's presence, but those of the community gathered around Jesus Christ's presence». That is why the first Christian apologists could say that, as opposed to the pagan worship practices, "the Christians have no altar, temple or offering» ${ }^{9}$.

It was only when it was clear to the Christians that the Lord would not return immediately, and after witnessing a continuous increase in the number of Christians, that they decided to put up churches at home and, later on, to build them. The oldest church known is in Dura Europos, by the Eufrates. The house was built during the 1st century and refurbished during the first half of the 3rd one as Domus ecclesia, with a great nave, as well as its own baptistery.

The first proper churches were built After Emperor Constantine officially acknowledged Christianity in 313, looking very much like Roman basilicas. Very soon there was a church in every city, serving simultaneously as Bishop's see (cathedral). In later centuries, many factors influenced the churchbuilding styles: not just theological ideas but also spiritual and earthly trends, which triggered changes in their architectural structure. Romanesque churches were followed by Gothic cathedrals, understood as God's cities on earth. Renaissance buildings were replaced by the royal halls of the Baroque ${ }^{10}$ and ancient styles were born again in the

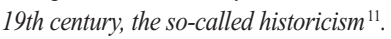

What are churches for the 21st century person, perceived as «testimonies in stone of Christian faith»? ${ }^{12}$ Churches are:

- Holy places. First of all, they are used to celebrate the liturgy, that is, they are built according to its needs. The consecrated temple becomes a special place «where the Christian community gathers in order to listen to God's words, to pray together and to celebrate the Eucharist and other sacraments. They are particular signs of the pilgrim Church on Earth and, simultaneously, portrays of the Church already in Heaven ${ }^{13}$.

- Places for various religious celebrations. Apart from the maximum expression of Christian liturgy - the celebration of the Eucharist - they also provide a special place for many other celebrations, such as the rest of sacraments and sacramental forms, the celebration of God's words, religious services, processions, etc. 
- Places for individual devotion. Most churches host several spaces —or part of them-for private prayer. Churches are places for retirement, places for prayer, personal meditation or the worship of saints.

That is, churches are places hosting the various manifestations of faith ${ }^{14}$. They are located at symbolic places, both with regard to urban structure and in the theological sense, given that churches mark the places where saints or people of particular relevance are buried; cemeteries or places where miraculous events have taken place and which have been venerated for years or even centuries.

Besides, churches are also places which have an impact on society, given that they stand for Christendom, which has marked a great part of the history of some cities and towns. Therefore, churches are places marking the identity of individuals or groups, both at the personalemotional level and at the level of preserving peoples' customs and faith. Churches are open to everybody as places of peace and tranquillity and, beyond their community use, they are linked to a region's cultural memory. They are very often places of an extraordinary artistic and architectural beauty, and this can also be applied to 20th century churches.

\section{Building churches in germany in the early 20th century}

This is neither the place nor the time to focus my presentation on the ambiguous scenario of Church and society in the early 20th century. Scientific discoveries were accompanied by numerous social changes. But we could start from the basis that this also had an impact on artists. Architects were somewhat lagging behind the trend of progress, but we could still refer to years of change. In view of this subject, I would like to focus on two specific points in time:

Firstly, I would like to recall a short text. Pope Pio X published on 22 November 1903 the motu proprio "Tra le sollicitudini» ${ }^{15}$, an instruction on sacred music ${ }^{16}$. Based on certain adverse situations in the field of religious music (unfortunately, it often happens that the Roman observations are not just made in order to influence something positively, but they use hardships as a reason for publication); Pope Pio $X$ formulates on the one hand a strong support which is typical of his time for Gregorian chant (art. 3), as well as for Pierluigi da Palestrina's classical polyphony (art. 4). We should mention that women were excluded from the chanted service at that time and they should be replaced by children (art. 13). On the other hand - and this should be quoted as an indication of a desirable el cristianismo ha marcado gran parte de la historia de las ciudades y de los pueblos. Por ello, las iglesias son lugares de identidad de los individuos o grupos, tanto en un nivel personal-emocional como de conservación de las costumbres y de la fe de los pueblos. Las iglesias se ofrecen a todas las personas como lugares de tranquilidad y de retiro y, más allá de su uso comunitario, se unen a la memoria cultural de una región. Muy a menudo son lugares de una calidad artística y arquitectónica excepcional; y esto también se puede aplicar a las iglesias del siglo XX.

\section{LA CONSTRUCCIÓN DE IGLESIAS EN ALEMANIA A PRINCIPIOS DEL SIGLO XX}

Este no es el momento ni el lugar para centrar la exposición en la ambigua situación de la sociedad y de la Iglesia a principios del siglo XX. Múltiples cambios sociales acompañaron a los descubrimientos científicos. Pero podemos partir de la base de que esto también influyó en los artistas. Los arquitectos estaban algo rezagados de este empuje del progreso, pero aún así podemos hablar de años de cambio. A la vista de este tema me gustaría centrarme en dos momentos concretos:

En primer lugar, quiero traer a la memoria un pequeño texto. El 22 de noviembre de 1903, el papa Pío X publicó el motu proprio Tra le sollicitudini ${ }^{15}$, una instrucción sobre la música sacra ${ }^{16}$. Partiendo de la base de ciertas situaciones adversas en el campo de la música religiosa (desgraciadamente, ocurre muchas veces que las observaciones romanas no se realizan sólo para influir de manera positiva sobre algo, sino que toman las dificultades como motivo de su publicación), el papa Pío X formula por un lado un fuerte apoyo, típico para su tiempo, del canto gregoriano (art. 3), así como de la polifonía clásica de Pierluigi da Palestrina (art. 4). Mencionamos aparte que en aquellos tiempos las mujeres estaban excluidas del servicio del canto, y que su parte debía ser sustituida por voces de niños (art. 13). Por otro lado - y esto hay que mencionarlo como indicación de un camino que se quiere seguir-, el Santo Padre hace hincapié en la participatio actuosa de los fieles (Prólogo); para que el espíritu cristiano florezca, hay que cuidar la santidad y la dignidad del templo. Los fieles deben alimentarse de esta fuente primera e indispensable ${ }^{17}$, así como de la participación activa de los Santísimos Misterios y en la solemne oración pública de la Iglesia.

A principios del siglo pasado hubo otro escrito - mejor dicho, un mandato, según el estilo al que acostumbraba el cardenal de Colonia Antonius Fischer - en el cual se establecía cómo construir iglesias en su archidiócesis: «Las nuevas iglesias han de ser construidas, por lo general, en los estilos románicos o góticos o en los llamados estilos de transición. Para nuestra circunscripción se recomienda básicamente el estilo gótico» ${ }^{18}$. Así reza la orden de 1912. Poco después de la Primera Guerra Mundial se puso gran énfasis en que todas las iglesias fueran erigidas en estos estilos. Los «estilos de construcción modernos» ya no se autorizaban. Los arquitectos deberían mantenerse en el espíritu existente de la arquitectura que se encontraba en las múltiples iglesias en Renania. 
El comienzo de la Modernidad a principios de la centuria, naturalmente tuvo su influencia, y no pasó desapercibido en el desarrollo de la construcción de iglesias en Alemania en el siglo XX. No es fácil determinar el momento exacto en el que esto ocurrió.

Las cuestiones que determinan la arquitectura después de la Primera Guerra Mundial en general y la construcción de iglesias en especial, no son nuevas. ¿En qué estilo debemos construir? era el título de un libro de aquella época que mostraba claramente en qué medida los arquitectos - pero también sus clientes - se preguntaban por la forma que iban a dar a sus construcciones. En la arquitectura aparecieron nuevos materiales de construcción, como el hormigón, el acero y su combinación, es decir, el hormigón armado. Además, como resultado de aquellos, apareció un nuevo uso del vidrio. Sin embargo, los ejemplos más famosos de los primeros años - la Faguswerke de Walter Gropius y Adolf Meyer (1911) ${ }^{19}$ o el Pabellón de Cristal ${ }^{20}$ de Bruno Taut en la Werkbundausstellung de Colonia en $1914^{21}$ - los encontramos en la construcción profana. Las iglesias importantes que utilizaron estos materiales fueron Saint-Jeande-Montmartre en París (1894-1904) ${ }^{22}$, de Antoine de Baudot, la iglesia de Otto Wagner en Steinhof, Viena, (1907) ${ }^{23}$, o — del mismo año-San Nicolás en Essen-Stoppenberg, de Carl Moritz.

Después de la Primera Guerra Mundial, la construcción de iglesias católicas (y también de las protestantes) ${ }^{24}$ se organiza de nuevo. Si quisiéramos sistematizar este desarrollo en Alemania podríamos, a grandes rasgos, hablar de dos tendencias básicas, expresadas de forma sencilla con los nombres de los arquitectos Rudolf Schwarz (1897-1961) y Emil Steffann (1899-1968) ${ }^{25}$.

Rudolf Schwarz entiende la construcción de iglesias como demostración y realización de esquemas sagrados, es decir, parte de una idea, o bien teológica o bien artística. Emil Steffann, sin embargo, atiende a los elementos del espacio para la comunidad y su celebración de la liturgia. Los dos - con diferencias y similitudes - se apoyan en los teólogos Johannes van Acken y Romano Guardini.

Van Acken era un párroco de Renania. Con su escrito, Christozentrische Kirchenkunst (El cristocentrismo del arte religioso) del año 1922, formula una cuestión básica en el entendimiento de la construcción de iglesias, exigiendo la concentración de la arquitectura y de la liturgia en el altar como centro del espacio. Escribe que «el altar como 'Cristo místico' debería ser el punto de partida y el punto central de la construcción y de la decoración de la iglesia». Con esto se sabe estrechamente unido al programa cristológico del papa Pío X, y considera esto incluso de manera más amplia, ya que dice que «todo el arte que está al servicio de Dios debe crear formas del presente verdaderas y nobles por medio del conocimiento espiritual de la herencia de pensamientos litúrgicos prácticos $\mathrm{y}$, con eso, conseguir en el espacio principal una obra de arte total y homogénea, completamente dominada por el divino Magister Atrium ${ }^{26}$.

Existieron muchas reacciones a este escrito. Desde el ámbito teológico se exigió que el auténtico teocentrismo - el que se refiere a Dios- no debiera perderse por una alusión fuerte y unilateral a Cristo. Pero también, path to follow - the Holy Father highlights the believers' "participatio actuosa» (Prologue); the holiness and dignity of the temple must be kept in order to allow the Christian spirit to flourish. The faithful should feed on this primeval and indispensable source ${ }^{17}$, and they should also take part in the Holy Mysteries and in the solemn public prayer at church.

In the early 20th century there was a writing, or rather a mandate, according to the style of Antonius Fischer, the Cardinal of Köln, which provided the way in which churches should be built in his archdioceses: "Generally, new churches must be built in Romanesque or Gothic styles, or in those termed as transition ones. The Gothic style is basically recommended for our circumscription» ${ }^{18}$. This is the wording of the 1912 mandate. Shortly after the First Great War, strong emphasis was made on building churches in these styles. Modern constructive styles were not allowed anymore. Architects should follow the predominant architectural style found in the churches of Rhineland.

At the start of the century, the onset of Modernity naturally exercised its influence. This did not remain unnoticed for the development of church-building in Germany in the 20th century. Determining when exactly it took place is not an easy task.

The issues determining architecture after the First Great War in general and church-building in particular are nothing new. "In Which Style Should We Build?» was the title of a book at that time clearly showing to what extent architects and their clients were wondering about the shape of their constructions. New building materials emerged in architecture, such as concrete, steel and their combination i.e. armoured concrete. Besides, glass acquired a new use as a result of the former. Nevertheless, the best-known examples from the first years - the Faguswerke by Walter Gropius and Adolf Meyer (1911) ${ }^{19}$ or the Glass Pavillion ${ }^{20}$ by Bruno Taut at the Werkbundausstellung of Cologne in 1914 21 - are found in profane construction. The most important churches using these materials were Saint-Jean-de-Montmartre in Paris (1894-1904) 22, by Antoine de Baudot, Otto Wagner's church in Steinhof, Vienna, (1907) ${ }^{23}$, or Saint Nicholas in Essen-Stoppenberg, by Carl Moritz in the same year.

After the First Great War, building Catholic churches (and also Protestant ones) ${ }^{24}$ is resumed. If we wished to classify this development in Germany, we could mention generally two basic trends which would coincide with the names of the architects Rudolf Schwarz (1897-1961) and Emil Steffann (1899-1968) ${ }^{25}$. 
Rudolf Schwarz understands the building of churches as a demonstration and realisation of sacred schemes, that is, as part of a theological or artistic idea. However, Emil Steffann pays attention to spatial elements for the community and the celebration of liturgy. Both of them - with certain differences and similarities - are based on the theologians Johannes van Acken and Romano Guardini.

Van Acken was a parish priest from Rhineland. He wrote «Christozentrische Kirchenkunst》 (Christocentric Religious Art) in 1922, posing a basic question for the understanding of churchbuilding and demanding that architecture and liturgy should focus on the altar as spatial centre. He writes that «the altar as mystical Christ should be the starting point and core of building and decorating a church». With that, he acknowledges his close link to Pope Pio X's Christologic programme. He even goes beyond it by writing that "every art at the service of God must create true and noble present shapes by means of the spiritual knowledge of the heirloom of practical liturgical thoughts and, thus, achieving at the main space a total and homogeneous work of art which is completely dominated by the divine Magister Atrium ${ }^{26}$.

Numerous reactions emerged from this writing. From the theologians' field, they claimed that the real theocentrism - the one which refers to God-should not be lost due to a strong unilateral reference to Jesus Christ. Besides, specific references were made among the architects, such as Dominikus Böhm who was then working with Martin Weber in a churchbuilding workshop belonging to some kind of architects' association ${ }^{27}$. They straightforwardly stated that the examples of church-building given were scarcely useful. For that reason, Böhm and Weber sent to the author their own designs (known as Circumstantes) which were collected in the second edition of Van Acken's book released in 1923. This is viewed as a theological-liturgical footprint leading to a leap in the development of church-building in the 20 s.

There is another footprint. The 20th century started with the so-called Liturgical or Innovating Movement. Some monks from the Benedictine monasteries of Solemnes and Mary Laach, in Belgium and Germany, respectively, as well as numerous members of the Catholic Youth Movement, searched for the origin of the true sources of the liturgy. Together with the Biblical Movement, they acknowledged the roots of faith and life in the configuration of supper during the community's meeting around the Lord's table. The Munich cleric Aloys Goergen experienced it

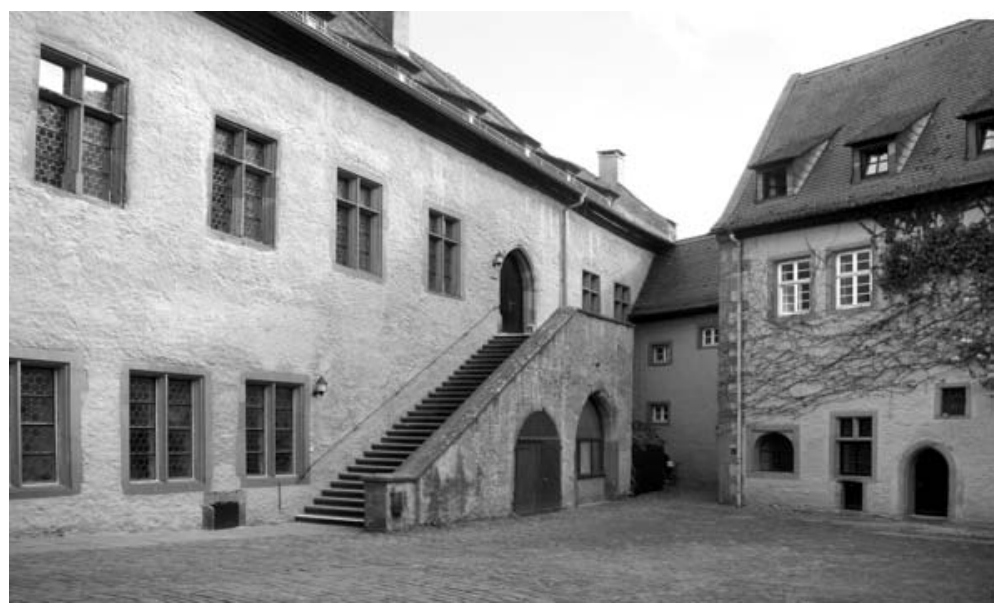

El castillo de Burg-Rothenfels en la actualidad.

entre los arquitectos, hubo referencias concretas, como la de Dominikus Böhm, que en aquel tiempo trabajaba con Martin Weber en el taller de construcción de iglesias en una especie de asociación de arquitectos ${ }^{27}$. Declaran directa y claramente que los ejemplos de construcción de iglesias ofrecidos son de poca ayuda. Por eso Böhm y Weber envían al autor sus propios diseños (que se llegan a conocer con el nombre de Circumstantes) y que encontraron cabida en la segunda edición del libro de Van Acken, que apareció en el año 1923. Esto lo quiero considerar como una huella teológico-litúrgica que lleva a un salto en el desarrollo de la construcción de iglesias en los años veinte.

Pero existe una segunda. El siglo XX comienza con un fenómeno que llamamos Movimiento Litúrgico o renovador. Monjes de los monasterios benedictinos de Solemnes y Maria Laach, en Bélgica y Alemania respectivamente, así como innumerables miembros del Movimiento de Juventud católico, buscan el origen de las verdaderas fuentes de la liturgia. Acompañados del Movimiento Bíblico, reconocen las raíces de la fe y de la vida en la configuración de la cena durante la reunión de la comunidad alrededor de la mesa del Señor. El clérigo Aloys Goergen, de Munich, que lo vivió personalmente, lo expresaba con las siguientes palabras: «En el umbral del siglo, en la grandeza de la experiencia de una vida en comunidad, se originó el paso del yo autónomo al descubrimiento del tú, del nosotros, de la comunidad, de la Iglesia. No se trataba de una protesta, ni de una rebelión, ni hubo ninguna desobediencia en ello» ${ }^{28}$.

Un lugar en el que se pueden constatar estos cambios es el castillo de Rothenfels-am-Main, cerca de Würzburg. Fue comprado poco después de la Primera Guerra Mundial por la asociación de juventudes católicas Quickborn y reformado totalmente a partir de 1924 por el arquitecto Rudolf Schwarz, con la participación activa del posterior capellán del castillo, 


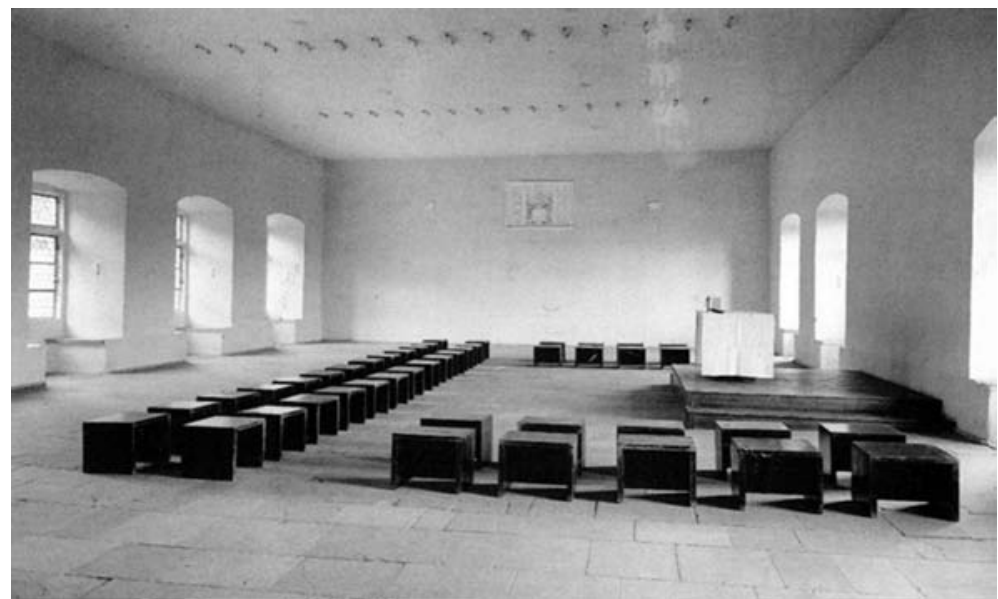

Rudolf Schwarz, adecuación litúrgica de la Sala de los Caballeros del Castillo de Rothenfels, 1928/29.

Romano Guardini. Lo que allí se estableció en el marco de numerosas semanas de vacaciones y de trabajo, por la observación concreta de los espacios modificados y por el ejercicio común de la palabra, de los gestos y del canto, supuso una enorme contribución para el catolicismo alemán en general y para la construcción de iglesias en particular, especialmente a la vista de las transformaciones producidas en la Iglesia Católica hasta el Concilio Vaticano II ${ }^{29}$. Al contrario que van Acken, Romano Guardini se apoya básicamente en la esencia de la liturgia ${ }^{30}$, y además considera la objetividad de la fiesta litúrgica y cómo ésta influye en la composición del espacio.

Existe una coincidencia que — hasta donde yo sé- sólo ha sido mencionada una vez y de forma escueta en la literatura alemana ${ }^{31}$, y que quizás - y permítanme que lo mencione en este lugar- demuestra más conexiones entre España y Alemania que las que conozco hasta ahora, que ayudan a la comprensión de la liturgia y a la construcción de iglesias. Romano Guardini publica en el año 1918 un pequeño tomo con el título Vom Geist der Liturgie (El espíritu de la liturgia) ${ }^{32}$, del que explicaré en seguida la enorme influencia que ha tenido en la construcción de iglesias en Alemania. En el mismo año aparece en Barcelona el libro El valor educativo de la liturgia católica ${ }^{33}$ de Isidro Gomá y Tomás, que posteriormente llegaría a ser Primado de España. No quiero hacer especulaciones sobre sus influencias específicas en la construcción de iglesias en España, pero tal vez merezca la pena investigar este asunto con más profundidad.

Volvamos a Romano Guardini: también se le califica como impulsor y creador del Movimiento Litúrgico (Hans Maier). Con el pequeño tomo ya mencionado Vom Geist der Liturgie, así como con Liturgische Bildung (Formación litúrgica) ${ }^{34}$ y Von Heiligen Zeichen (Signos sagrados) ${ }^{35}$, crea un nuevo punto de vista. En ellos busca honradamente respuestas a estas personally and thus wrote the following words: "At the threshold of the century, experiencing the greatness of community life, the autonomous ego moved on to the discovery of you, of us, of the community, of the Church. It was not a protest or a rebellion and there was no disobedience in it $\rangle^{28}$.

The Castle of Rothenfels-am-Main, near Würzburg, is a place where these changes may be seen. It was purchased shortly after the First Great War by the Quickborn association of Catholic youth and totally refurbished from 1924 on by the architect Rudolf Schwarz, together with the active participation of the future castle chaplain, Romano Guardini. What went on in that place for several weeks of holidays and work, after the concrete observation of modified spaces and the joint conversations, gestures and chants made an enormous contribution to German Catholicism in general and church-building in particular, specially in view of the changes undergone by the Catholic Church till the II Vatican Council ${ }^{29}$. As opposed to Van Acken, Romano Guardini is based on the essence of the liturgy ${ }^{30}$ and also considers the objectiveness of the liturgical feast and how it impacts the spatial composition.

There is a coincidence which, as far as I know, has only been quoted once and briefly by the German literature ${ }^{31}$ and which may show more connections between Spain and Germany -let me mention it here and now - than those known so far and which foster the comprehension of the liturgy and the building of churches. Romano Guardini published in 1918 a small volume titled ca «Vom Geist der Liturgie» (About the Spirit of Liturgy) ${ }^{32}$. I will try to explain the huge impact it has caused on church-building in Germany. The book «El valor educativo de la liturgia católica» (The Educational Value of the Catholic Liturgy) ${ }^{33}$ by Isidro Gomá $y$ Tomás who would later become Primate of Spain was published the same year. I would not wish to speculate on its specific influences on churchbuilding in Spain but it may be worth researching this subject in greater depth.

Let us return to Romano Guardini: he was also quoted as the promoter and creator of the Liturgical Movement (Hans Maier). With the already-mentioned small book «Vom Geist der Liturgie», as well as "Liturgische Bildung» (Liturgical Education) ${ }^{34}$ and «Von Heiligen Zeichen» (About Sacred Symbols) ${ }^{35}$, he created a new viewpoint. In his books, he honestly searched for answers to those questions - which are not just with regard to his time - and he also provides recommendations about a specific know-how and points towards a new line of thought. He explains the relativity of personal devotion, of popular celebrations and of the maximum forms 

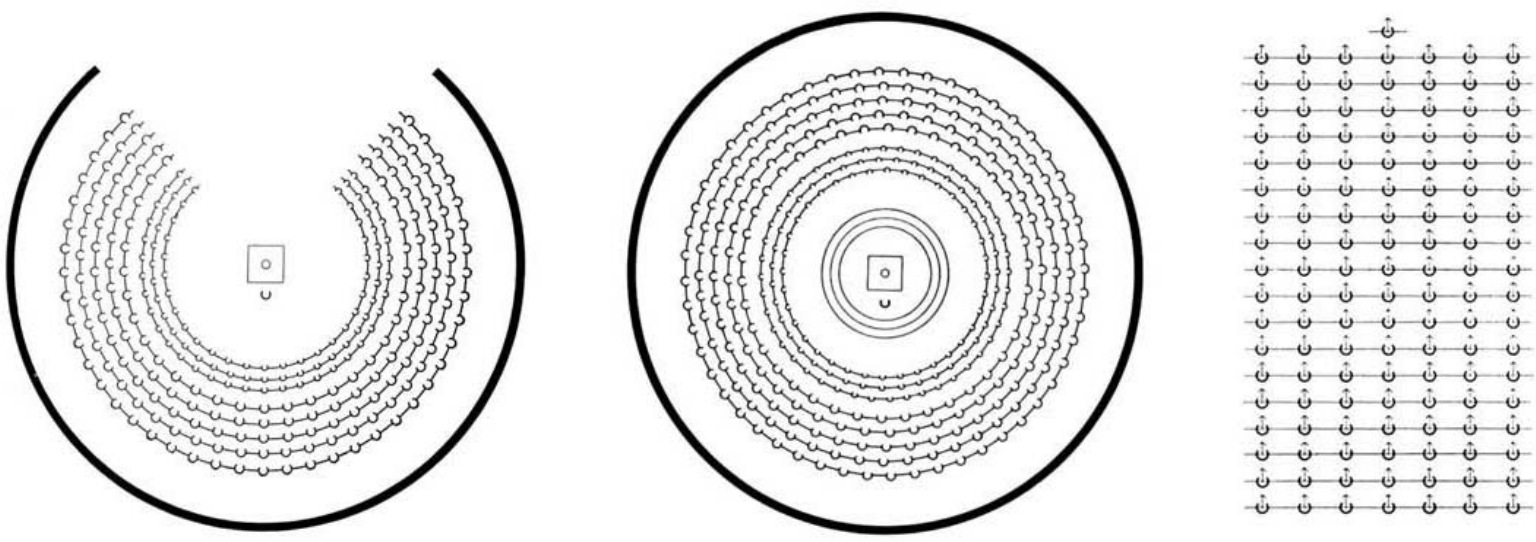

Rudolf Schwarz, esquemas teóricos sobre la configuración del espacio culto (del libro Vom Bau der Kirche, 1938): el anillo abierto, el anillo cerrado y el camino.

of liturgy, pointing out the nonsense of any liturgy directed exclusively to God. He analyses simple actions and symbols and says that a relaxed contemplation and a serious execution will take us to the primitive essence and to a decent behaviour. According to his diagnosis: "Our time is ripe for liturgy due to our interior need. We must learn to express our inside on the outside and to read our inside from the outside. We must be able to accept symbology again ${ }^{36}$. Guardini's thoughts and ideas refer to the basic understanding of the liturgy and thus, even nowadays, they foster a change in religious life - provided they are taken seriously - and properly applied.

These works were done at Rothenfels Castle and formulated as theoretical writings or instructions to follow a direction, and found their particular expression in the transformation of the Chapel and Hall of the Knights ${ }^{37}$. The small chapel, which had been used by the villagers of BurgRothenfels as a church since 1910, was emptied by Rudolf Schwarz. "We felt that, through our actions, something was destroyed here, since the first thing we created was an empty space. We found the strength to destroy the old because we wanted to try something totally new. To tell the truth, we did not mean to create something empty, but a different abundance» ${ }^{38}$. This abundance was fostered by those who gathered here to pray and to celebrate the Eucharist. These were very deep thoughts, as shown by a lighting chart explaining the lighting recommended by the various gatherings.

Schwarz formulates the idea of the new churchbuilding even more clearly with the transformation preguntas - que no sólo son de su tiempo-, da indicaciones sobre un modo de hacer concreto e indica una dirección de pensamiento. Explica la relatividad de la piedad personal, de las celebraciones populares y de las formas máximas de la liturgia, e indica el sinsentido de toda liturgia que apunte solamente a Dios. Analiza los actos y signos sencillos y señala cómo una contemplación tranquila y una ejecución seria nos trasladan a la primitiva esencia y a un comportamiento digno. Su diagnóstico dice: «Nuestro tiempo está maduro para la liturgia por nuestra necesidad interior. Debemos aprender a expresar nuestro interior en nuestro exterior, y leer del exterior nuestro interior. Tenemos que volver a ser capaces de aceptar la simbología» ${ }^{36}$. Los pensamientos e ideas de Guardini se refieren a la comprensión básica de la liturgia, y por eso llevan - siempre que se toman en serio y se aplican adecuadamente - a un cambio en la vida religiosa, incluso todavía hoy.

Estos trabajos, hechos en el castillo de Rothenfels, formulados como escritos teóricos o como instrucciones para seguir una trayectoria, encontraron una expresión especial en la transformación de la Capilla y de la Sala de los Caballeros ${ }^{37}$. La pequeña capilla, que había sido utilizada desde 1910 por los habitantes del pueblo de Burg-Rothenfels como iglesia, fue vaciada por Rudolf Schwarz. «Sentíamos que por medio de nuestros actos, algo era destruido aquí, ya que lo que primero creamos fue un espacio vacío. Encontramos el valor para destruir lo viejo porque queríamos probar algo totalmente nuevo. A decir verdad, no queríamos crear algo vacío, sino crear una abundancia distinta ${ }^{38}$, una abundancia que sustentaban aquellos que se reunían aquí para rezar y para celebrar la eucaristía. Estos eran pensamientos muy profundos, como pone de manifiesto un esquema de luces que muestra la forma de iluminación que se recomienda para los distintos tipos de reuniones. 


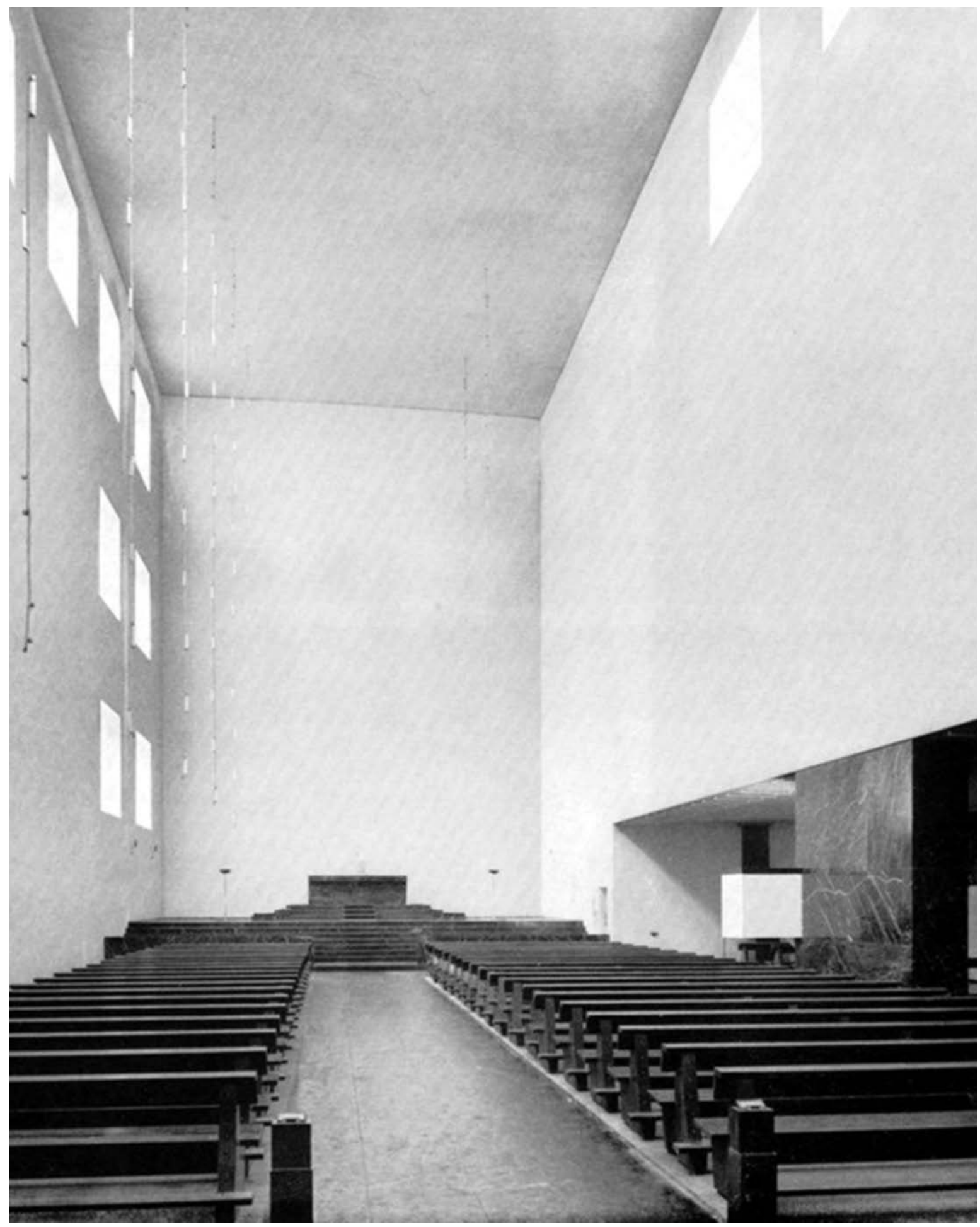

Rudolf Schwarz, iglesia del Día de Corpus (Fronleichnamskirche), Aquisgrán (Alemania), 1928/30 
of the Hall of Knights into a party and celebration hall. "The only equipment in the hall was 100 stools, small black wooden cubes. That was all. The architecture became a clean white container. The other space, the live one, should be created by the community itself... It is beautiful when the sacred space melts totally with the community and in their actions, when it is built through the liturgy, when it disappears again with it and when every architectural action is disposed of. There is nothing else in space at first and later, nothing else is left but space: the Lord has passed by ${ }^{39}$. Schwarz describes these two spatial solutions with the notions of open ring and closed ring. These expressions sound like prototypes. They are terms belonging to a primitive architecture developed from the basic forms of cultural behaviour ${ }^{40}$. Architect Rudolf Schwarz wishes to show that they stand for human thinking and making. Thus, when he talks about a parish community, it is distributed as a horseshoe, along three sides of the space, looking at centre with the altar raised on some stairs. Every glance is directed towards it; they are grouped and thus directed outside the space. With the closed ring, he refers to the ideal shape of a circle. The altar is in the centre. Everything is directed to it: $« A$ big hall is not required in order to celebrate the Lord's Eucharist. The only thing needed is a table at the centre and a dish with bread and a chalice with wine upon it. The table can be decorated with candles and it can be surrounded with chairs for the community. That is all: table, space and walls constitute the simplest church» ${ }^{41}$.

Another basic shape to which he properly refers is the path. To him, this is a transformation of the open ring, the possibility to adapt the configuration to a bigger community, given that the orientation towards the altar is perfected in everyone's common orientation. They can all walk towards their meeting with God and, thus, the imagined procession has its goal.

The first German churches to be built with armoured concrete can be mentioned as a specific example: the church of the Holy Sacrament (Fronleichnamkirche) in Aachen ${ }^{42}$. RudolfSchwarz led the Aachen School of Fine and Applied Arts since 1926, and he made several projects for that church along 1929 (four at least). Even after he began the works, during 1930 Passover, several minor changes took place and the final details were decided at that time. The community celebrated the consecration of their church on 21 December 1930.

Saint Makai became a role model for 20th century church-building, and not only in Germany, but also abroad. Hermann Baur, an architect who
Schwarz formula la idea de la «nueva construcción de iglesias» aún más claramente con la transformación de la sala de los caballeros en una habitación para fiestas y celebraciones. «Como único equipamiento, la habitación tenía cien taburetes, pequeños cubos negros de madera. Esto era todo. La arquitectura se convirtió en un recipiente limpio y blanco. El otro, el espacio vivo, lo debería crear la comunidad por medio de sus reuniones. Aquí se hizo realidad esta idea: que una comunidad puede crear espacios por sí misma... Es hermoso cuando el espacio sagrado se funde totalmente con la comunidad y en sus actos, cuando se construye por medio de la liturgia, cuando desaparece otra vez con ella y cuando se prescinde de cualquier actuación arquitectónica. Al principio no hay nada más que el espacio, y después no queda nada más que el espacio: el Señor ha pasado» ${ }^{39}$.

Schwarz describe estas dos soluciones espaciales con las nociones de anillo abierto y de anillo cerrado. Estas expresiones parecen prototipos. Son términos de una arquitectura primitiva, desarrollada desde las formas básicas del comportamiento cultual ${ }^{40}$. El arquitecto Rudolf Schwarz quiere mostrar con ellos que son expresión del pensar y del hacer humanos. Así, cuando habla de un anillo abierto en el cual una comunidad parroquial se coloca en forma de herradura, según tres lados de este espacio, dirigidos hacia un centro en el que está situado el altar elevado sobre unos escalones, todas las miradas se dirigen hacia él, son aglutinadas y se dirigen de esta forma fuera del espacio. Con el círculo cerrado se refiere a la forma ideal de un círculo. En su centro está el altar. Todo se dirige hacia él: «Para celebrar la eucaristía del Señor no hace falta una habitación muy grande. Sólo hace falta en el centro una mesa, y sobre ella un plato con pan y un cáliz con vino. La mesa se puede adornar con velas y rodearla con asientos para la comunidad. Esto es todo. Mesa, espacio y paredes forman la iglesia más simple» ${ }^{41}$.

Otra forma básica de la que habla con todo derecho es la del «camino». La ve como una transformación del «anillo abierto», una posibilidad de configuración adecuada para una comunidad mayor, puesto que en la orientación común de todos se perfecciona la atención hacia el altar. Se puede ir al encuentro de Dios conjuntamente, y de esta manera, la procesión imaginada tiene una meta.

Como ejemplo concreto de esto se pueden mencionar las primeras iglesias en Alemania que fueron construidas con hormigón armado: por ejemplo, la iglesia del Santísimo Sacramento («Fronleichnamkirche») en Aquisgrán ${ }^{42}$. Desde 1926, Rudolf Schwarz dirige la Escuela de Artes y Oficios de Aquisgrán, y a lo largo del año 1929 elabora varios proyectos para esta iglesia (por lo menos cuatro). Incluso después de comenzar la obra, en la Pascua de 1930, se efectuaron varios pequeños cambios; y durante la misma se decidieron los últimos detalles. El 21 de diciembre de 1930, la comunidad celebró la consagración de su iglesia.

«San Makai» se convirtió en un ejemplo a seguir en la construcción de iglesias del siglo XX. Y no sólo en Alemania, sino también más allá 
de sus fronteras. Hermann Baur, un arquitecto amigo de Rudolf Schwarz, dice que con St. Fronleichnam todo lo que había estado en el aire sobre la construcción de iglesias hasta finales de los años veinte, había sido expuesto de una forma válida. Todo lo meramente accidental, todas las formas decorativas que se habían producido alrededor de la construcción de iglesias fueron eliminadas, casi barridas. La arquitectura yace aquí como última desnudez, como envoltura de un espacio con unas medidas perfectas —el elemento base de la conducción de la luz- que sirven al culto y a la razón de ser de una casa para Dios.

La descripción más completa de este edificio procede de la pluma del mismo arquitecto: «Entonces recibí el encargo de construir la Fronleichnamkirche en Aquisgrán. La decisión provenía del comitente, que quería combinar la iglesia con un culto eucarístico especial. Para nosotros llegó a ser un concepto: la iglesia no sólo debería llamarse del Cuerpo del Señor, sino que también debía llegar a serlo.

»Es muy fácil describir esta iglesia porque tiene muy pocos elementos, básicamente dos: la zona para la comunidad, desacostumbradamente alta, y una nave lateral muy baja. Las dos juntas forman un rectángulo perfecto sobre el plano. Hasta la altura de la nave lateral, la construcción está completamente cerrada. No tiene ventanas y las puertas son piezas planas de acero que fueron recubiertas de cobre. Detrás de los muros opacos no existe nada más que puro espacio interior. Después de la última esquina de la nave lateral se llega a un atrio que recibe toda la luz a través de un gran paño de vidrio. Como material de construcción se eligió el vidrio, porque posibilita la visión pero no el acceso. Desde el atrio y a través de la pared de cristal se puede ver la nave lateral con sus confesionarios, el Vía Crucis y el altar de María y, con ello, el muro ciego de la nave mayor y, al final, el altar. De esta manera se ha conseguido un filtro ante el lugar santo por medio de diversos habitáculos, y el camino hasta allí está obstaculizado. La nave lateral se abre a la nave mayor en toda su longitud; un solo pilar, en el centro, soporta la pared superior. La nave mayor es un espacio único, perfecto. El suelo, acabado con piedra azul oscura, termina en los escalones que suben hasta el altar; y allí se hace más valioso, de mármol de Namur, así como el altar. Pero no existe un 'sancta sanctorum' separado: el pueblo y su Señor están en el mismo espacio común, que está rodeado de altas paredes blancas. La luz entra desde arriba a través de una hilera de ventanas cuadradas, cae por encima del altar y desaparece. La pared del altar carece de ventanas.

»Hemos tratado de conseguir formas simples, básicas, en forma de cubo, y hay que mencionar que sólo las cruces ceremoniales de piedra son cilíndricas. La luz artificial procede de lámparas que están colgadas del techo por medio de cables forrados de seda en forma de espiral. Pueden encenderse en grupos, y de esta manera se puede crear espacio a través de la luz. La luz llega a ser un material de construcción» ${ }^{43}$.

De esta manera se crea un espacio eclesial en medio del suburbio caótico de Aquisgrán, cuyo principio es la caja: el espacio único sin columnas. Hasta el día de hoy se ha discutido mucho sobre la desnudez de este habitáculo. was a friend of Rudolf Schwarz, said that with St. Fronleichnam everything which had been unclear about church-building until the late 20s had been adequately explained. Everything which was purely accidental, every decorative shape which had been used for church-building had been eliminated, almost vanquished. Architecture emerged as the final nakedness, as the cladding of a space with perfect measurements - lighting as the key element-at the service of the cult and as a raison d'etre for the house of God.

The most complete description of that building comes from the same architect: "I was assigned to build the Fronleichnamkirche in Aachen. The decision was made by the client who wanted to combine the church with a special Eucharist service. This was the concept that we followed: the church should not only be called Lord's Body, it should also become it.

"This church can be described very simply, since it has a few elements, basically two: the community area which is unusually high and a very low side nave. Both of them constitute a perfect rectangle on the plan. The building is totally closed up to the height of the side nave. There are no windows and the doors are flat steel pieces covered in copper. There is nothing behind the opaque walls but pure interior space. After the last corner in the side nave, you reach an atrium receiving all of the light through a big glass pane. Glass was chosen as building material because it allows vision but not access. The side nave and its confession booths may be seen through the atrium and through the glass wall, as well as the way of the cross and Mary's altar, together with it, the blind wall of the main nave and, finally, the altar. Thus, a filter before the holy place has been achieved by means of different rooms, thus hindering the way towards it. The side nave opens in its whole length to the main one. One pillar, at the centre, is holding the upper wall. The main nave is a perfect and unique space. The floor is finished with dark blue stone and it ends at the stairs leading to the altar. It becomes more valuable there, made of Namur marble, as well as the altar. But there is no separate sancta sanctorum: the people and their Lord are in the same common space surrounded by white walls. Light comes in from above through a row of square windows, it falls on the altar and disappears. There are no windows in the altar wall.

»We have tried to obtain simple, basic cube-like shapes. It is worth mentioning that only the ceremonial stone crosses are cylindrical. Artificial light comes from lamps hanging from the ceiling by spiral silk-wrapped wires. They can be switched 
on group by group and thus create space through light. Light becomes a building material» ${ }^{43}$.

This is how a church space was created in the midst of Aachen's chaotic outskirts, a space based on the box principle: a single column less space. Much has been said so far about the nakedness of this dwelling. Shortly after the construction was completed, Romano Guardini described this church by saying that this way of building was already present in medieval mysticism: «This is not a void, this is silence! God is in silence». He added: "With regard to the lack of figures in this holy place, the void is also a figure. There is no contradiction: a void which is correctly formed as regards space and surface is not a rejection of them, but quite the opposite. The relationship is the same one, such as the one between silence and speech. As soon as people get used to it, they feel a mysterious presence in it expressing the holiness of that which goes beyond any shape and name» ${ }^{44}$.

Rudolf Schwarz also assigned in this instance the later artistic finishings to his colleagues from Aachen School of Fine Arts. Hans Schwippert designed the benches, while Anton Schickel took care of the gold and silversmithing, together with his students and those from Wilhelm Giesbert's class. The way of the cross was made by Wilhelm Rupprecht, while the eternal light chandelier and the small altar cross were made by Schwerdt, and the tabernacle by Walter Ditsch.

According to Schwarz, the church space is basically divided into three areas: the first one is this world's space, where people gather, that is, the church nave; the second one is the threshold area, where Jesus Christ lives (in Aachen that would be the presbytery above the tiers); and the third one, behind it, would be "God's unreachable place» ${ }^{45}$, the place where we address our prayers, the dimension from which we receive God's answer: the tabernacle and the empty white wall.

I have mentioned as archetypical the ideal notions of the open ring, the closed ring and the path. Schwarz also mentions the light chalice and the dark chalice: the latter is some sort of open ring looking upwards and the former is a parable. There are two more, not worth mentioning here for clarity purposes ${ }^{46}$. With that, Rudolf Schwarz sets the bases which cannot be ignored if we are discussing about contemporary religious architecture. They are valid themselves and contain the history of religious architecture, given that they develop "the two main basic shapes (...), the central one and the longitudinal one, the central building and the longitudinal one» ${ }^{47}$.

Something happened at Rothenfels Castle which necessarily left a trace. Direct perception and the experience of worshipping in a small -and
Poco después de acabada la construcción, Romano Guardini hace una descripción de esta iglesia. Indica que ya en la tradición de la mística medieval existe esta manera de construir: «Esto no es un vacío; jesto es silencio! Y en el silencio está Dios». Y añade: «En cuanto a la falta de imágenes de este lugar santo, el vacío en sí ya es una imagen. Dicho sin contradicción: un vacío correctamente formado respecto al espacio y la superficie no es ninguna negación de ellos, sino el polo opuesto. La relación es la misma, como la del silencio con la palabra. Tan pronto como el hombre se acostumbra a ello, siente en ella una presencia misteriosa, que expresa la santidad de aquello que sobrepasa cualquier forma y nombre» ${ }^{44}$.

También en este caso, Rudolf Schwarz encomienda a sus colaboradores de la Escuela de Artes de Aquisgrán el posterior acabado artístico. Los bancos los diseña Hans Schwippert; del trabajo de orfebrería se encarga Antón Schickel, con alumnos suyos y de la clase de Wilhelm Giesbert. El Vía Crucis lo ejecuta Wilhelm Rupprecht, el candelabro de la luz eterna y la pequeña cruz del altar Fritz Schwerdt, y el sagrario lo hace Walter Ditsch.

Para Schwarz, el espacio de la iglesia se divide básicamente en tres zonas: el espacio de este mundo, en el que se congrega el pueblo, que es la nave de la iglesia; la zona del umbral, allí donde vive Cristo (en Aquisgrán, esto sería el presbiterio sobre el graderío), y detrás «el lugar inaccesible de Dios» ${ }^{45}$, el lugar al que dirigimos nuestras oraciones, la dimensión de la que recibimos la contestación de Dios: el tabernáculo y la pared blanca vacía.

He mencionado como prototípicos los esquemas ideales del «anillo abierto», el «anillo cerrado» y el «camino». Schwarz menciona también el «cáliz claro» y el «cáliz oscuro»: éste último es una especie de anillo abierto orientado hacia arriba, y aquél, una parábola. También hay otros dos, cuya mención aquí no nos aclararía nada ${ }^{46}$. Con esto, Rudolf Schwarz sienta unas bases que no pueden ser ignoradas en la discusión sobre la arquitectura religiosa hasta nuestros días. Son válidas en sí mismas y contienen la historia de la arquitectura religiosa, ya que desarrollan las «dos grandes formas básicas (...), la forma central y la forma longitudinal, la construcción central y la construcción longitudinal» ${ }^{47}$.

En el castillo de Rothenfels ocurrió algo que, necesariamente, ha tenido que dejar huellas. La percepción directa, la experiencia de la memoria del culto en un círculo pequeño - y también grande - han tenido su efecto en el posterior desarrollo de la comprensión de la liturgia. Por un lado, los que habían participado en estas celebraciones y convivencias en el castillo de Rothenfels son los que han expandido estas ideas. Por otro, ocurrió algo que no admite vuelta atrás: la presencia del Señor ha sido iluminada, el «lumen praesens» habita entre nosotros, el altar ha ocupado el centro del mundo.

Romano Guardini ${ }^{48}$, el guía paternal de Quickborn, habló - independientemente de cualquier acontecimiento concreto - del ambiente que se vivió a principios de los años veinte del siglo pasado con las siguientes palabras: «Un acontecimiento religioso de insospechado alcance está 
teniendo lugar: la Iglesia despierta en las almas ${ }^{49}$. Esta imagen se ajusta muy bien a la descripción de la situación en la que se encontraba el catolicismo en los años y décadas siguientes.

La confluencia de personalidades y las circunstancias del castillo de Rothenfels fueron tan excepcionales, que la semilla sembrada germinó y dio frutos. «No fue por Rothenfels, pero sin Rothenfels no hubiera ocurrido que la lengua materna relevase al latín en la Iglesia de una forma natural, sin ningún gesto revolucionario. No fue por Rothenfels, pero sin Rothenfels no hubiera ocurrido que la comunidad participase en el cáliz eucarístico. La Iglesia había exigido a esta generación de pioneros una dolorosa renuncia, y fue imposible que esto surgiera de una juventud que seguía igual que los mayores, conservando su autenticidad y su identidad ${ }^{50}$.

Era el «kairos» el que se abría camino en esta sociedad, y era como «el paso del Espíritu Santo a través de su Iglesia», como dijo el papa Pío XII en su discurso final al primer Congreso Nacional Litúrgico Pastoral en Asís en septiembre de 1956, refiriéndose al Movimiento Litúrgico.

\section{OTROS IMPORTANTES CONSTRUCTORES DE IGLESIAS EN ALEMANIA}

Aproximadamente al mismo tiempo, Dominikus Böhm planeaba construir varias iglesias, entre ellas, una en Colonia (St. Engelbert) y otra en Regensburg (St. Wolfgang) ${ }^{51}$. En ambas se partió de la idea del espacio central, y sin embargo encontramos en ellas dos versiones muy diferentes de esta idea.

A St. Engelbert (1930/32) el pueblo la empezó a llamar inmediatamente «el exprimidor de limones». Está construida sobre una sencilla planta en forma de círculo, con ocho láminas en forma de parábola que están entrelazadas entre sí. A través de una escalera grande se llega al interior, con una iluminación limitada, y a través de otra escalera se llega al altar, que está colocado de forma caprichosa y con mucha iluminación. Se respetó la exigencia de una construcción central y se colocaron seiscientos asientos alrededor. El espacio se concentra en el altar, ayudado por dos escaleras, así como por la trayectoria de la luz.

St. Wolfgang fue construida pocos años después, entre 1938 y 1940. Aquí encontramos un diseño parecido al de St. Engelbert, aunque esta vez hecho sobre una base elíptica. El representante, no de los arquitectos, sino de los promotores, Josef Habbel, exigió la aplicación consecuente de la idea del espacio central. Por la escasez de materiales a causa de la guerra, no se pudo construir la iglesia con hormigón armado por fuera y pilares de acero por dentro, sino con arcos de piedra sobre una cruz griega como diseño básico. Los arcos de piedra hacían que la construcción pareciera más imponente. Tiene una entrada baja y a la vez amplia, seguida de un espacio principal alto, más luminoso y en general relativamente estrecho. La impresión de catedral que transmite se refuerza por la colocación de los focos litúrgicos. El gran zócalo del altar, conjuntamente con el bloque del mismo, colocado en el centro, abre nuevos caminos para el desarrollo de las iglesias y de la liturgia en Alemania (y en otros lugares). also big-circle had their impact on the later development of the comprehension of the liturgy. On the one hand, those who had taken part in those celebrations and gatherings at Rothenfels Castle are the ones who promoted these ideas. On the other hand, something irretraceable occurred: the Lord's presence was lit up, the lumen praesens lives among us; the altar has occupied the centre of the world.

Romano Guardini ${ }^{48}$, the guiding father of Quickborn, spoke thus about the atmosphere experienced in the early 20 s of the past century -regardless of any specific event-: «A farreaching religious event is taking place: the Church is waking up in the souls» ${ }^{49}$. This image befits the description of the scenario that the Catholic Church was going through in those years and in the following decades.

The meeting of personalities and the circumstances of the Rothenfels Castle were so extraordinary that the seed sown germinated and blossomed. «It was not due to Rothenfels, but without Rothenfels, mother tongues would not have replaced Latin at church in a natural way, with no revolutionary gestures. It was not due to Rothenfels, but without Rothenfels, the community would not have taken part in the Eucharistic chalice. The Church had demanded a painful renunciation from this pioneer generation, and it would have been impossible to emerge from a youth who remained just like their elders, preserving their authenticity and identity ${ }^{50}$.

It was the kairos opening its way through this society, and it was like «the Holy Ghost walking among its Church", according to the words of Pope Pio XII in his last speech of the National Liturgical Pastoral Conference in Assisi, in September 1956, when he referred to the Liturgical Movement.

Other relevant church builders in Germany Approximately at the same time, Dominikus Böhm was planning to build several churches, one of them in Köln (St. Engelbert) and another one in Regensburg (St. Wolfgang) ${ }^{51}$. Both of them sprang from the idea of the central space, however, they present very different versions of this idea.

St. Engelbert (1930/32) was immediately termed by people the lemon squeezer. It is built upon a simple circular plan, with eight intertwined layers in the shape of a parabola. The interior is reached through a big staircase with scarce lighting and the altar is reached through another staircase. The altar is placed in a fussy way, with plenty of light. The space focuses on it, supported by two staircases and by the light trajectory.

St. Wolfgang was built a few years later, between 1938 and 1940. Its design is similar to 
St. Engelbert's, though elliptical this time. Josef Habbel, who was the developers' representative, demanded a consistent implementation of the central space idea. Due to lack of materials as a consequence of the war, the church could not be built using armoured concrete outside and steel pillars inside, so they had to use stone arches upon a Greek cross as the basic design. The stone arches made the building appear grander. The entrance is low but wide and the main space is tall, lighter and relatively narrow in general. The big altar base, together with its block at the centre, opens new paths for the development of churches and liturgy in Germany and in other places.

Hundreds of new churches were built during the 50 s in Catholic bishoprics and in the Protestant churches of the Länder. «Some of these churches show an excessive search for a new style, nevertheless, some are exceptional», according to the architecture critic G.E. Kidder Smith in the early $60 s^{52}$. Among them, we could undoubtedly quote Saint Lawrence, in Munich-Gern, by Emil Steffann, Mehlem and Siegfried Östreicher.

On 27 November 1955 and after 18 months of planning, the most representative work, both by Emil Steffann and as a general example of German religious architecture ${ }^{53}$. Its architectural style is defined by modesty and simplicity. Or, according to Emil Steffann, by its "poverty and simplicity» ${ }^{54}$, "by the balance and authenticity of materials ${ }^{55}$. It is convincing as a building for a community of 8,000 or 9,000 souls, since it realises the promoter's wish, the Oratorians priest community: providing a proper image to the celebration of the liturgy as a gathering around the Lord's table.

The wide plot was a big prairie with old trees downtown. The requirements were a church, a chapel for the celebration of religious services with children, spaces for the youth (this was done for the first time in Munich archbishopric) and a parish house for several priests. It was surrounded with five-storey housing blocks at the West and by two-storey semi-detached houses at the South. There was a group of small orchards at the East and by a canal, nowadays called Nymphenburg. The architects used the green areas and natural slopes to create a holy zone, with the main church, the attached halls and the parish house arranged in U-shape. Thus, a huge entrance court was made with some kind of porch leading to the church space.

The church was made of brick, which was cheaper than armoured concrete. The interior faces of the church are plastered in white, the ceiling frame was built with no joints, but with pinewood planks painted blue with a fishbone drawing. Natural

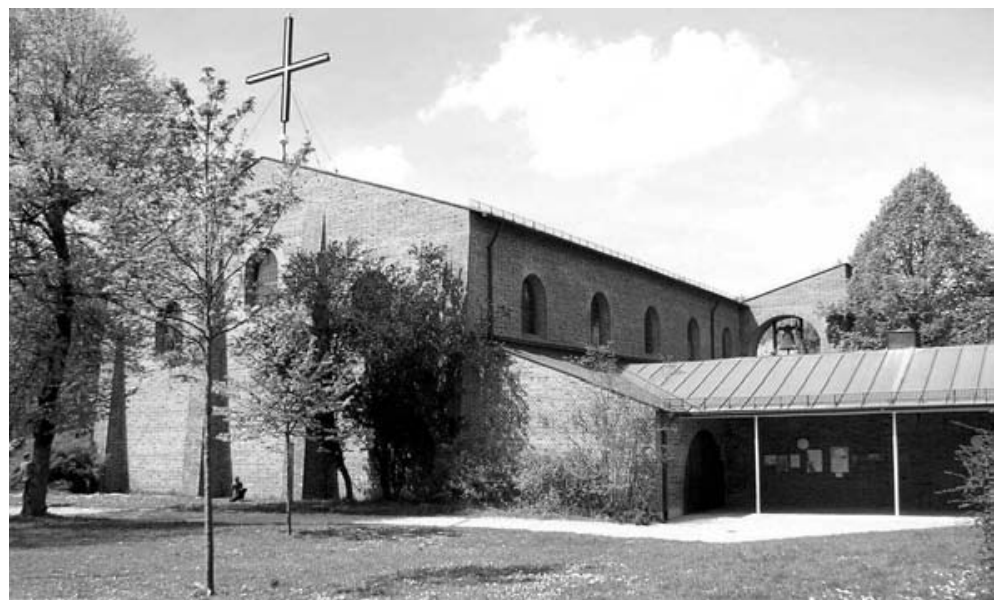

Emil Steffan, San Lorenzo, Munich (1955).

En los años cincuenta se construyeron cientos de nuevas iglesias en los obispados católicos y en las iglesias protestantes de los Länder. «Algunas de estas iglesias demuestran una búsqueda algo forzada de un nuevo estilo. Sin embargo algunas son magistrales», dijo el crítico de arquitectura G.E. Kidder Smith a principios de los años sesenta ${ }^{52}$. Entre éstas se encuentran, sin duda, San Lorenzo, en Munich-Gern, de Emil Steffann, Mehlem y Siegfried Östreicher.

El 27 de noviembre de 1955 y después de dieciocho meses de planificación, fue inaugurada la que, desde el principio, figuró como la obra más representativa tanto de Emil Steffann como de la arquitectura religiosa alemana en general ${ }^{53}$. Su estilo arquitectónico se define por su modestia y sencillez. O como dice Emil Steffann, por su «pobreza y sencillez»" ${ }^{54}$, «por el equilibrio y la autenticidad de los materiales» ${ }^{55}$. Convence como construcción para una comunidad de ocho a nueve mil almas, porque realiza el deseo del promotor, la comunidad sacerdotal de los Oratorianos: dar una imagen adecuada a la celebración de la liturgia como reunión alrededor de la mesa del Señor.

El amplio solar era una gran pradera con viejos árboles en el centro del pueblo. Los requerimientos eran una iglesia, una capilla para celebrar servicios religiosos con niños, espacios para la juventud (esto fue la primera vez que se hizo en el arzobispado de Munich) y una casa parroquial para varios sacerdotes. Estaba rodeada por bloques de vivienda de cinco pisos y por casas adosadas de dos pisos al oeste y al sur; al este, por una colonia de pequeños huertos y por un canal, hoy en día el canal Nymphenburg. Los arquitectos usaron las zonas verdes y los desniveles naturales del terreno para crear una «zona santa», con la iglesia principal y con las dependencias anexas y la casa parroquial dispuestas en forma de U, de manera que se creó un gran patio de entrada con una especie de pórtico que conduce hacia el espacio de la iglesia. 


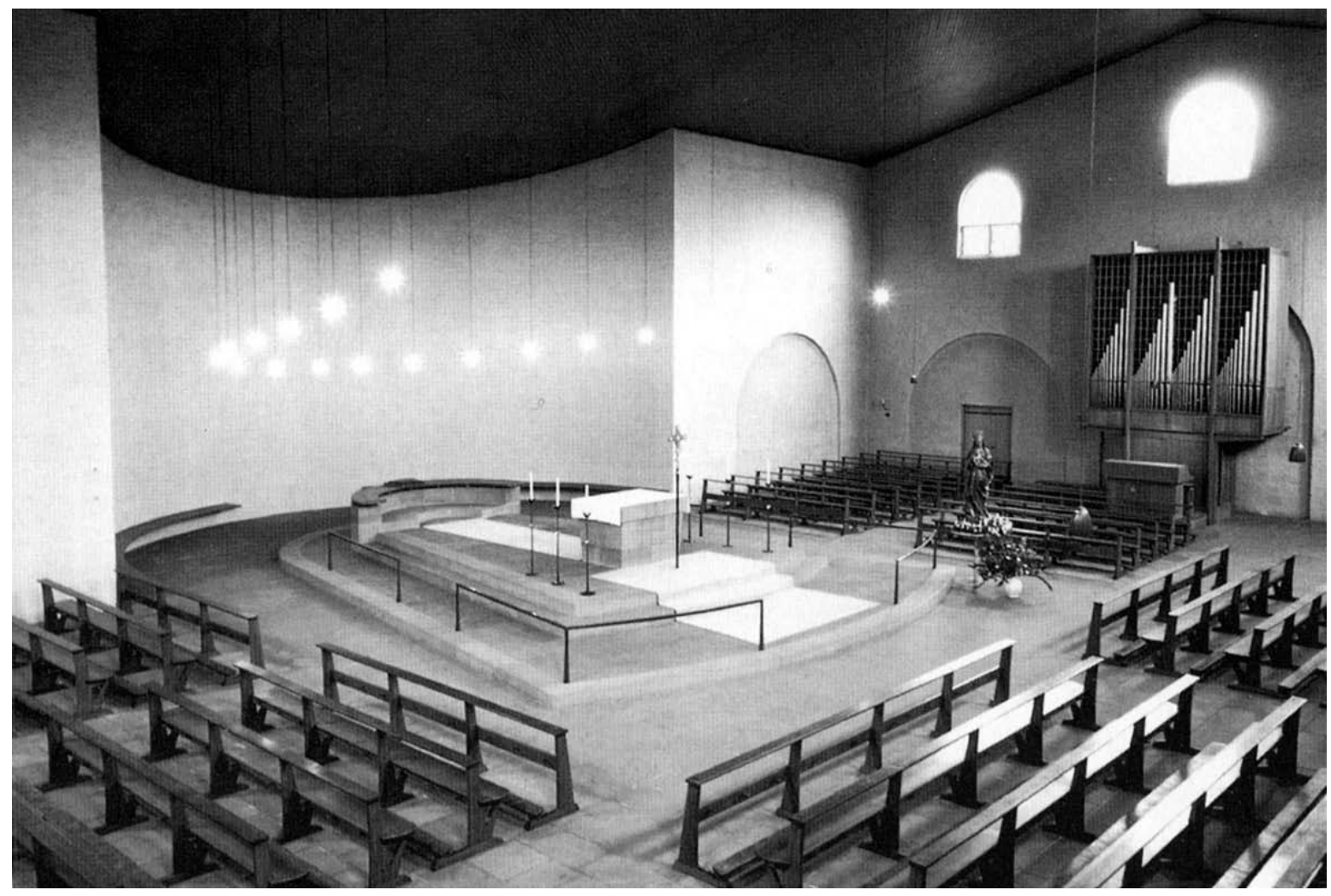

Emil Steffan, San Lorenzo, Munich (1955).

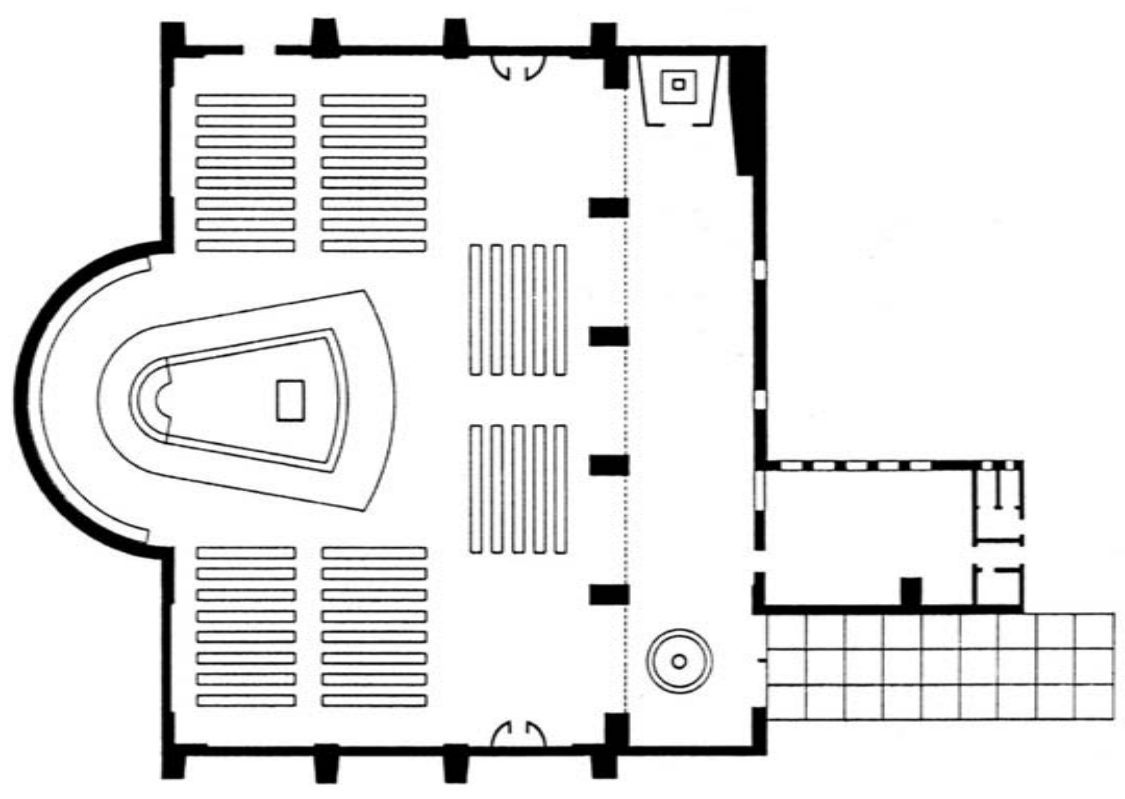


grey stones were used for the floor and smoked dark oak wood was used for the benches, doors and confession booths.

Entrance to the church is made through a low attached nave allowing a view into the community square space through five arches. Inside the barn-shaped church, the community gathers around the altar along three blocks or spines coming from the apse. The circle around the Lord's table is complete with a big bench for the priests. Another bench leaning on the apse wall is designed for the choir. The tabernacle for the holy sacrament has its own altar located opposite the baptismal font at the end of the side nave. This configuration had to be specifically authorised by Munich's Cardinal, Julius Döpfner, since it did not correspond to the 50s liturgical protocol. Besides, the altar in the middle of the community was also unusual at that time.

We could continue to describe the original status of this church without any problem, since it is perfectly apt for the current times. This shows to what extent both architects were pioneers in their times, with their configuration of the community space. After the II Vatican Council, there was no need to carry out the compulsory changes to interior spaces. The priest would celebrate mass facing the believers from the late 50s and not after 1965, time when the new provisions came into force. During its construction, the altar and the most relevant elements in the church had been placed in the spot provided by the Church ten years later.

The inside still remains the same as 50 years ago. Then, just like now, light came from three semi-circular arched windows located on top. The original and simple electrical bulbs are still kept inside their copper holders. It still conveys the spirit of Franciscan simplicity and clarity. A specific chapel for the baptismal font was built one year later, something already planned by Emil Steffann in 1961. There are still plans from the early 60s for a kindergarten, new facilities for the parish centre and a hostel. All of those buildings were built at the Northern side of the big plot, clad in brick.

Saint Lawrence's church in Munich has been a role model from its construction. The community gathering around the spiritual core, i. e., the altar, is still today as it used to be, a useful example for religious architecture, even after year $2000^{56}$

\section{Brief theological reflection on the church space}

Saint Lawrence is not very far away from the II Vatican Council, since it provided basically what had already been shown in the church. In order to express it in a theological manner, I would like to recall the
La iglesia se construyó de ladrillo, ya que resultaba más económico que construirla con hormigón armado. Los paramentos interiores de la iglesia están enfoscados en blanco, el entramado del tejado se construyó sin empalmes y fue realizado con tablones de pino pintados de azul y con un dibujo en espina de pez. Para el suelo se emplearon piedras naturales grises y para los bancos, las puertas y los confesionarios, madera de roble oscuro ahumado.

La entrada a la iglesia se hace a través de una nave baja antepuesta o anexa, que por medio de cinco arcos permite ver el espacio cuadrado para la comunidad. En la iglesia, con forma de pajar, la comunidad se reúne alrededor del altar, en tres bloques o lenguas que provienen del ábside. El círculo alrededor de la mesa del Señor se cierra mediante un gran banco para los sacerdotes. El banco que se apoya en la pared del ábside está pensado para el coro. El tabernáculo, lugar donde se reserva el Santísimo, tiene su propio altar en frente de la pila bautismal que se encuentra al final de la nave lateral. Esta disposición tuvo que ser autorizada específicamente por el cardenal de Munich, Julius Döpfner, porque no se correspondía con el protocolo litúrgico de los años cincuenta. También el altar ubicado en medio de la comunidad resultaba completamente desacostumbrado en esa época.

Podríamos continuar describiendo el estado original de esta iglesia sin ningún problema, ya que tiene perfecta cabida en nuestros días. Esto demuestra en qué manera estos dos arquitectos se adelantaron a los tiempos con su configuración del espacio para la comunidad. Después del Concilio Vaticano II no hizo falta realizar las obligadas transformaciones de los espacios interiores. El sacerdote celebraba la misa frente a los fieles ya desde finales de los años cincuenta y no después de 1965, cuando entraron en vigor las nuevas disposiciones. Durante su construcción, el altar y todos los elementos importantes de la iglesia habían sido colocados tal como diez años después llegaría a ser preceptivo por parte de la Iglesia.

El espacio interior sigue siendo igual que hace cincuenta años. Entonces, como hoy, recibía su iluminación a través de tres ventanas en arco de medio punto situadas en lo alto. Aún conserva sus sencillas bombillas eléctricas originales, dentro de sus soportes de cobre, y sigue transmitiendo el espíritu de la sencillez y la claridad franciscanas.

$\mathrm{Al}$ año siguiente se construyó una capilla específica para la pila bautismal, que ya había sido prevista por Emil Steffann en 1961. Existen todavía planos de principios de los años setenta para un jardín de infancia, nuevas dependencias del centro parroquial y un albergue. Todos estos edificios fueron construidos en el lado norte del gran solar y revestidos de ladrillo.

Ya desde el primer momento de su construcción, la iglesia San Lorenzo, en Munich, ha servido como guía. El agrupamiento de la comunidad alrededor de un centro espiritual - el altar - sigue siendo, como antaño, un ejemplo válido para la arquitectura religiosa, y esto también después del año $2000^{56}$. 


\section{BREVE REFLEXIÓN TEOLÓGICA SOBRE EL ESPACIO ECLESIAL}

San Lorenzo no está muy lejos del Concilio Vaticano II, pues allí se recogió especialmente lo que en ella ya se había demostrado. Para expresarlo de forma teológica, quiero recordar las palabras que Emil Josef Lengeling, el gran científico litúrgico de Münster, dirigió a los más eminentes teólogos conciliares de aquel tiempo, especialmente durante la fase de transición de finales de los años sesenta y principios de los setenta: «La liturgia es el diálogo entre Dios y el hombre» ${ }^{57}$. O, dicho de otra manera, ya que la liturgia como celebración de la muerte y resurrección de Nuestro Señor tiene otras dimensiones centrales, significa «la memoria del pasado y, además, la liberación del presente» ${ }^{58}$. La liturgia es, «en su significado más profundo, la actualización de la obra salvadora de Cristo. Es la acción conjunta del representante de Cristo en la tierra y de su Iglesia para la santificación de los hombres y para la glorificación de Dios» ${ }^{59}$.

El lugar en la Biblia en donde se expresa más ampliamente el significado de la liturgia durante la misa es en Mateo 18, 20: «Donde hay dos o tres reunidos en mi nombre, allí estoy Yo en medio de ellos». Esta expresión no se refiere solamente a la celebración de la eucaristía, que va a ser nuestro siguiente punto de referencia, sino a cualquier otra forma de reunión de los creyentes.

Los padres del Concilio Vaticano II constataron que la liturgia «es la acción sagrada por excelencia», «la cumbre a la cual tiende la actividad de la Iglesia y, al mismo tiempo, la fuente de donde mana toda su fuerza» ${ }^{60}$. El espacio arquitectónico que se emplea para ello debe satisfacer unas exigencias muy altas: muy altas tanto desde el punto de vista de la liturgia como en lo que respecta a su forma estética. Tengo que confesar que lo habitual en muchas de nuestras iglesias no es demasiado esperanzador. Por ejemplo, tiestos con flores, moquetas parcialmente gastadas $\mathrm{y}$ tablones con testimonios infantiles que, con su mejor intención, hacen referencia a la Primera Comunión o similares. Cosas que, por desgracia, no podemos evitar. Muchas veces, el visitante de una iglesia así se pregunta por qué el lugar del encuentro con Cristo y con Dios tiene precisamente esta forma de expresión; porque las iglesias deben contener muchas cosas, pero nunca cosas que tendríamos en casa entre nuestras cuatro paredes. Hay que decir esto porque, por un lado, es importante tener en cuenta los contenidos litúrgicos teológicos y la forma de la construcción artística; pero también es importante una reflexión sobre la orientación ambiental de nuestras iglesias.

\section{LA CONSTRUCCIÓN DE IGLESIAS A FINALES DEL SIGLO XX}

He subtitulado mi ponencia «En busca de una casa para Dios y para el hombre». Hay varias razones para ello. Nombraré dos. Por un lado, la frase que, según el espíritu de los años noventa, pronunció el arquitecto suizo Mario Botta después de haber construido una serie de capillas e words addressed by Emil Josef Lengeling, the great liturgical scientist from Münster, to the most eminent council theologians of that time, particularly during the transition phase in the late 60 s and early 70 s: "The liturgy is a dialogue between God and human beings ${ }^{57}$. Or, in other words, since the liturgy as the celebration of Jesus Christ's death and resurrection has other central dimensions, it means «the memory of the past and the release from the present ${ }^{58}$. The liturgy is, «in its deepest meaning, the updating of Jesus Christ's saving action. It is the joint action of Christ's representative on Earth and of its Church for the sanctification of human beings and for God's glorification $\rangle^{59}$.

The exact place in the Bible where the meaning of the liturgy during mass is best expressed is Matthew 18, 20: "For where two or three are gathered in my name, there am I among them». This expression refers not just to the Eucharistic celebration, which will constitute our next reference point, but also to any other means of believers'gathering.

The fathers of the II Vatican Council stated that the liturgy "is the sacred action by excellence», "the summit at which the Church's activity aims, and, simultaneously, the source from which its whole strength derives» ${ }^{60}$. The architectural space used for it should satisfy the highest expectations: very high, both from the liturgical point of view and from its aesthetic form. I must confess that the usual thing in many of our churches is not really hopeful. For instance, we find flowerpots, partially worn carpets and notice boards with kids' testimonials referring —in good will - to the First Communion and similar things. These are unfortunately unavoidable things. Often when visiting a church, we wonder why the meeting place with Jesus Christ and God is expressed particularly so; why is it that churches should contain lots of things, but never those things that we would keep at home. It must be said because, on the one hand, it is important to bear in mind theological liturgical contents and the form of artistic construction; but on the other hand, it is also important to reflect upon the atmospheric orientation of our churches.

\section{Church-building in the late 20th century}

My paper is subtitled In Search of a House for God and for Men. There are several reasons for this, of which I will simply mention a couple. On the one hand, the sentence uttered by the Swiss architect Mario Botta following the spirit of the 90s, after having built a series of chapels and even Evry cathedral, near Paris: "When I designed God's house, I also thought of a house for people» ${ }^{61}$. I have also been inspired by a chapter under the same name from the relevant document by the 
German bishops from 2003: «Missionarische Kirche sein. Offene Kirchen. Brennende Kerzen. Deutende Worte» (Be a missionary church. Open churches. Burning candles. Guiding words ${ }^{62}$. Their long second chapter is titled «Offene Kirchen. Gotteshäuser und Häuser für die Menschen» (Open Churches. God's Houses and Houses for People). In five sections, the bishops deal with the possibilities provided by church buildings for the stakeholders. A beautiful reflection is made: "The church building and its space open God's transcendence to the world. People need these places which are open to Heaven ${ }^{63}$.

These are two basicremarks about the transcendental functions related to the topic of building churches or church buildings, as well as for those who design and inhabit them.

What is new about the current building of churches? Few new works are made, although they are more than it is commonly thought, but most of them are church refurbishments. I would like to mention that the current discussion on the use of churches for other purposes is a topic to consider. That is because everything developed so far is the basis on which churches were built and, possibly, in the future they will not be used for that purpose. Now it is about closing down or assigning churches. According to some recent surveys, approximately $2 \%$ of German churches were closed down since 1990 and it is expected that approximately 3\% of them will be demolished or assigned till 2015. Every occasion on which a church is closed down or demolished is painful, since these buildings were erected as places of God's presence in the world $^{64}$. But we must admit that, unavoidably, we will have to say goodbye to some buildings in a near future. The German Episcopal Conference's document from 2003 deals with these issues, under the title "Re-using Churches», as well as the travelling exhibition «Schätze! Kirchen des 20. Jahrhunderts» (Treasures! 20th Century Churches) in which I have collaborated.

I would like to use three significant words in order to explain church refurbishments or adaptations in recent years: space, light and liturgy.

\section{Space}

As an introduction, I would like to mention an example of what the idea of an open or closed ring means to me. I will start with an architect's words to a bishop:

"As I hand over the key to this house, I believe that, as an architect, I have played a small part in its construction, but I have always been aware of the service that this house will give us. I have dreamt of the following. I have imagined that this house is the place where Christians will meet to live together and to act, to take care of incluso la Catedral de Evry, cerca de París: «Cuando diseñé la casa para Dios, también pensé en la casa para los hombres» ${ }^{61}$. Y también me he inspirado en un capítulo con el mismo nombre del importante documento de los obispos alemanes del año 2003: «Missionarisch Kirche sein. Offene Kirchen. Brennende Kerzen. Deutende Worte» (Sed una iglesia misionera. Iglesias abiertas. Velas encendidas. Palabras que guían) ${ }^{62}$. Su extenso segundo capítulo tiene como título «Offene Kirchen. Gotteshäuser und Häuser für die Menschen» (Iglesias abiertas. Casas para Dios y casas para los hombres). En cinco subtítulos, los obispos se ocupan de las posibilidades que ofrecen los edificios de las iglesias para todos los interesados. Ahí encontramos una reflexión tan bella como la siguiente: «El edificio de la iglesia y su espacio abren la trascendencia de Dios al mundo. Los hombres necesitan de estos lugares que abren el cielo» ${ }^{63}$.

Se trata de dos indicaciones claras sobre las funciones trascendentales que contiene el tema de la construcción de iglesias —o de edificios eclesiales - y para aquéllos que los diseñan, que los viven.

¿Cuál es la novedad en la actual construcción de iglesias? Se realizan pocas obras nuevas, aún siendo más de las que habitualmente se piensa, pero se trata básicamente de reformas de iglesias. Quiero mencionar que la discusión actual sobre la utilización con otros fines de las iglesias es un aspecto a tener en cuenta. Porque todo lo que ha sido desarrollado hasta ahora es la base sobre la que se construyeron las iglesias, y posiblemente, en el futuro, no van a ser utilizadas como tales. Ahora se trata de cerrar iglesias o de cederlas. Según encuestas recientes, desde 1990 se han cerrado aproximadamente el $2 \%$ de las iglesias en Alemania, y hasta el año 2015 se calcula que serán demolidas o cedidas aproximadamente un $3 \%$. Cada cierre de una iglesia, cada demolición, produce dolor, pues son edificios que fueron construidos como lugares de la presencia de Dios en el mundo ${ }^{64}$. Pero hay que admitir que va a ser inevitable que nos tengamos que despedir de algunos edificios en un futuro cercano. De estas cuestiones se ocupa el documento de la Conferencia Episcopal Alemana «Reutilización de iglesias» de 2003, así como la exposición itinerante «Schätze! Kirchen des 20. Jahrhunderts» (¡Tesoros! Iglesias del siglo XX), en la cual he cooperado.

Quiero utilizar tres palabras muy significativas para exponer las reformas o adaptaciones de las iglesias en los últimos años: espacio, luz y liturgia.

\section{Espacio}

Como introducción, me gustaría mencionar un ejemplo de lo que para mí representa la idea de un «anillo», abierto o cerrado. Quiero empezar con las palabras de un arquitecto a un obispo:

«En el momento de entregarle la llave de esta casa, pienso que, como arquitecto, he tenido una pequeña parte en su construcción, pero siempre he sido consciente del servicio que esta casa nos va a prestar. He soñado lo siguiente. Me he imaginado que esta casa será un lugar donde se encuentren 


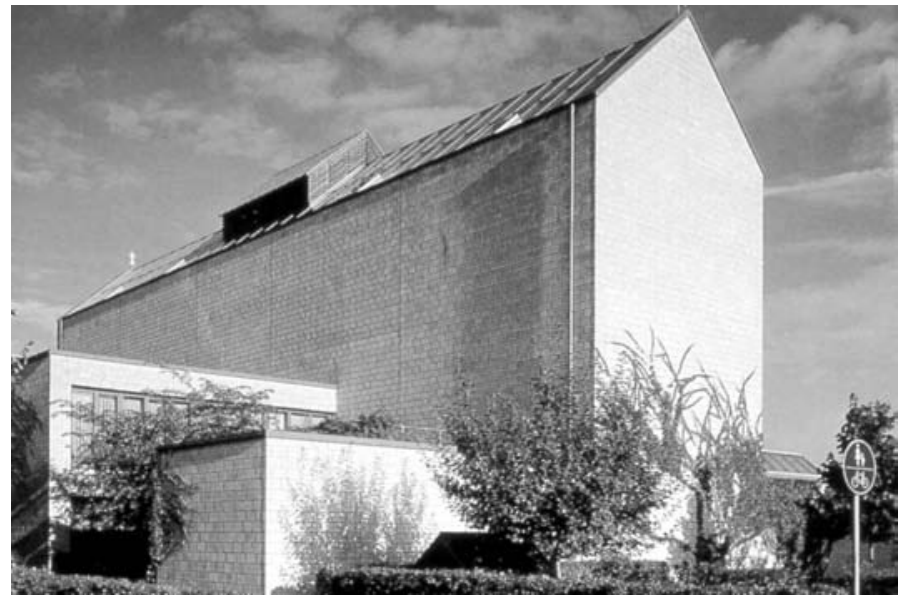

Ottokar Uhl, San Judas Tadeo, Karlsruhe-Neureat, 1979/89.

los cristianos para convivir y actuar, para ocuparse los unos de los otros, para poner una señal en el mundo. Me he imaginado que de esta casa saldrán preguntas incómodas para una sociedad opulenta y saciada, que desembocarán en unos cambios en la sociedad alejados de la violencia, con una fuerza y dinámica que experimentamos en Alemania del Este en estos días. Me he imaginado que esta casa podría ser el lugar de la Idea, de la discusión abierta, sin coacciones, dentro de la Iglesia. Me imagino que será una casa para llorar y para reír, para todos aquellos que viven en ella, que será un centro para las obras de los hombres, para unas obras que se expandirán con un significado universal lejos de aquí» ${ }^{65}$.

Estas palabras las pronunció el arquitecto austriaco Ottokar Uhl el 3 de diciembre de 1989, en su discurso al arzobispo Oskar Saier durante la entrega de la iglesia San Judas Tadeo en Karlsruhe-Neureut ${ }^{66}$. Este discurso fue el final de un proceso de desarrollo y comunicación que duró casi diez años: Uhl ganó un concurso para la construcción de una iglesia en el año 1980. Este encargo y su participación activa para la concreción del proyecto finalizaron con aquellas palabras.

En el complejo están integrados la iglesia, un jardín de infancia, una sacristía y la vivienda del sacerdote. Ottokar Uhl construyó un espacio de forma transversal en el que la comunidad se reunía alrededor de un zócalo en forma de $\mathrm{T}$. La idea de variar los espacios según el tamaño de la comunidad no fue llevada a la práctica, pero es significativa la disponibilidad del espacio para reaccionar a composiciones distintas de la comunidad. Desde la reunión de los creyentes, surge cada vez una nueva forma de liturgia: un intercambio entre Dios y el hombre. Según las diversas situaciones de comunicación, los hombres contestan a la palabra de Dios mediante su adoración, con la oración o con cánticos, creando con ello una nueva unión. Podemos imaginar distintas figuras de este espacio. each other and to place a sign in the world. I have figured out that uneasy questions to a sate and rich society will leave this house, and that they will trigger some changes in that society, detached from violence, with the strength and boost experienced nowadays in Eastern Germany. I have imagined that this house could be a place for Ideas, for open discussions, without coercion, inside the Church. I guess that this house will be for tears and laughter, for all who live in it, for some works which will acquire a universal meaning far away from here ${ }^{65}$.

These were the words by the Austrian architect Ottokar Uhl on 3 December 1989, during his speech before Archbishop Oskar Saier during the delivery of Saint Jude Thaddeus church in Karlsruhe-Neureut ${ }^{66}$. This speech marked the ending of a development and communication process lasting almost a decade: Uhl won a tender for building a church in 1980. This assignment and his active participation in the materialisation of the project ended with those words.

The facilities comprise a church, a crèche, a sacristy and the priest's house. Ottokar Uhl built a transversal space where the community gathered around a T-shaped plinth. The idea of changing the spaces according to the community size was not realised, however it is significant that the space can adapt, reacting to different configurations of community. The gathering of believers always creates a new form of liturgy: an exchange between God and human beings. Depending on the various communicative scenarios, people answer God's words by worshipping him, with prayer or with singing, thus creating a new union. We could imagine different figures in this space. The Munich Heart of Jesus (Herz-Jesu) church is completely different. This is an example of the so-called path scheme for the assembly. It was completed in 2000, when a young team of Munich architects (Allman-Sattler-Wappner) won a tender for projects. A new church had to be built since the old one was burnt. They built the best-known church in recent years, both at domestic and international levels. The most striking are two huge doors, $14.20 \mathrm{~m}$ high and $18.80 \mathrm{~m}$ wide. The blue glass surfaces were designed by the artist Alexander Beleschenko, still living in England. Beleschenko carved with nails - following his own calligraphy specifically designed for this work- several texts from Saint John's gospel. These gates are usually closed and the entrance is a simple double door in the centre of the main façade. You need to go through a very low, almost stifling corridor in order to reach a wide and well-lit space: the house inside the house principle has been practised here. The 


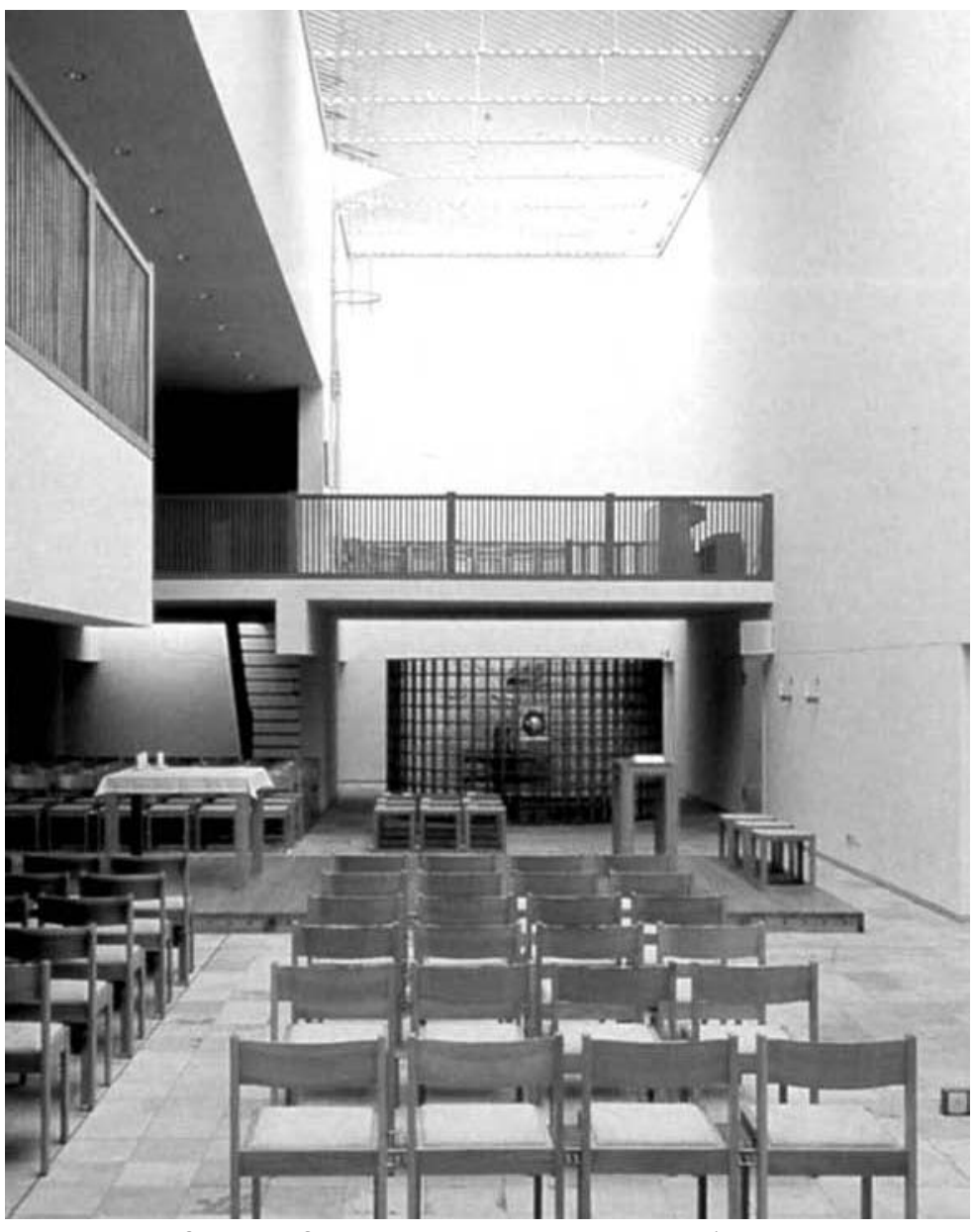

Ottokar Uhl, San Judas Tadeo, Karlsruhe-Neureat, 1979/89.

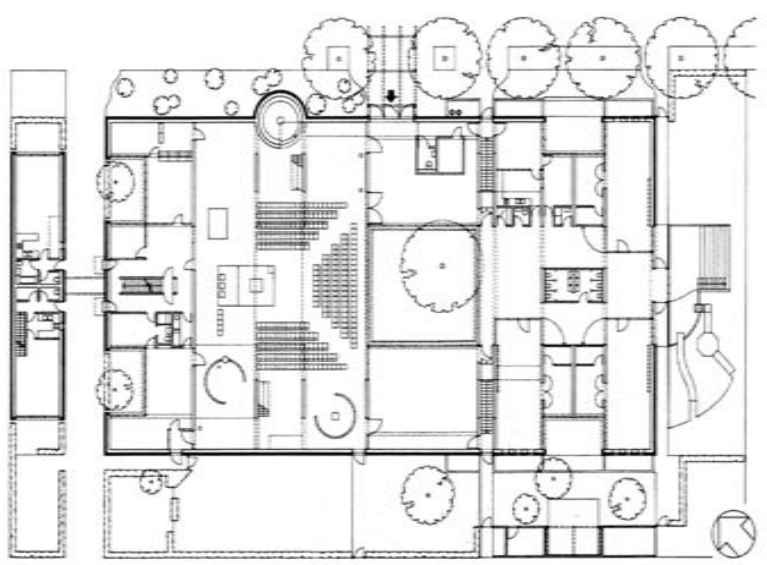




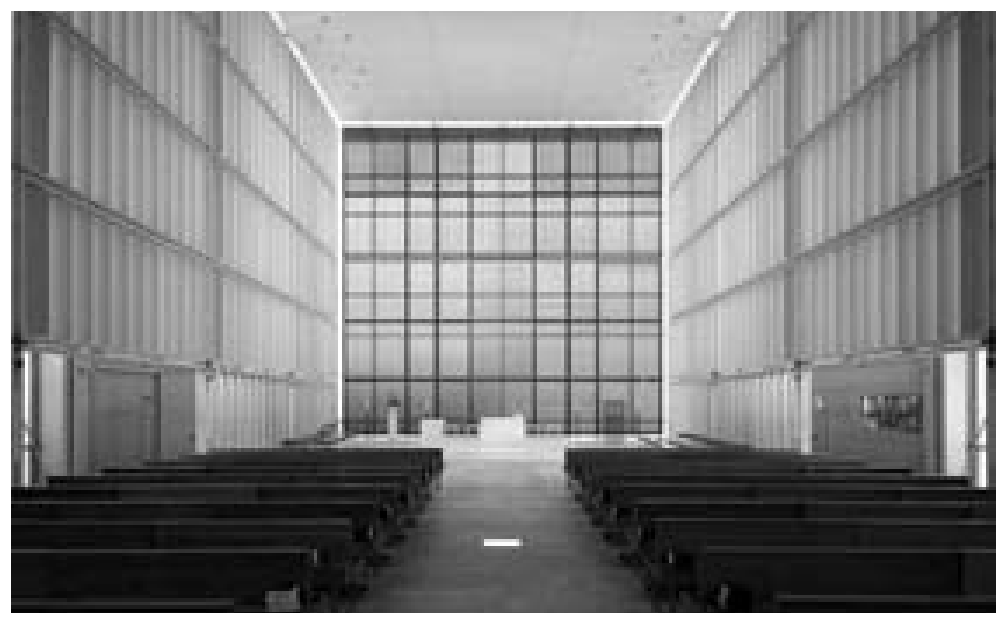

Allmann Scattler Wappner, iglesia del Corazón de Jesús (Herz-Jesu), Munich-Neuhausen, 1996/2000.

Completamente distinta es la iglesia del Corazón de Jesús (HerzJesu) de Munich ${ }^{67}$. Es un ejemplo del llamado «esquema camino» para la asamblea. Fue terminada en el año 2000, después de que un joven equipo de arquitectos muniqueses, Allman-Sattler-Wappner, ganara un concurso. Había que construir una iglesia nueva porque la antigua se había quemado: y se construyó la iglesia más renombrada de los últimos años, tanto a nivel nacional como internacional. Lo que llama poderosamente la atención son unas puertas inmensas, con una altura de 14,20 m. y una anchura de 18,80 m. Las superficies de cristal azul fueron diseñadas por el artista Alexander Beleschenko, que aún vive en Inglaterra. Beleschenko graba con clavos - en una caligrafía propia diseñada específicamente para esta obra- diversos textos del Evangelio según San Juan. Habitualmente estos portones están cerrados; por ello la entrada es una sencilla doble puerta en el centro de la fachada principal. A través de un pasadizo muy bajo, casi agobiante, se llega a un espacio amplio y luminoso: aquí se ha puesto en práctica el principio "casa dentro de casa». La caja exterior de cristal contiene dentro una estructura de madera. Hacia el altar, las ventanas son cada vez más opacas, y por lo tanto, menos transparentes. En los pies de la iglesia existe un inmenso balcón para el órgano. Los laterales están recubiertos de láminas de madera de arce; por una parte, esto hace que la iglesia tenga una buena acústica, y por otra, que deje pasar una cantidad adecuada de luz. Las láminas también separan de manera visible el altar del espacio perimetral, para que la atención se fije sobre éste. El así llamado «Tapiz de la Cruz» es un diseño de la pareja de artistas Lutzenberger-Lutzenberger. Está realizado de latón y cambia de aspecto según la incidencia de la luz. A la vista del visitante y de la comunidad congregada, se encuentra el gran presbiterio; los bancos laterales que rodean el altar prácticamente no se utilizan. outer glass box contains a wooden structure. The windows become more and more opaque and less transparent towards the altar. There is a huge balcony for the organ at the foot of the church. The sides are covered in maple wood planks, which enhance the church acoustics and allow a sufficient amount of light to pass through. The planks also separate visually the altar from the perimeter space, so that attention is focused on the former. The so-called Tapestry of the Cross is designed by a pair of artists: Lutzenberger-Lutzenberger. It is made of brass and changes its look depending on the light intensity. The big presbytery can be seen by the visitors and by the community gathered there, while the side benches surrounding the altar are rarely used.

\section{Light}

Not only medieval cathedrals made obvious the meaning of light for architecture, but also contemporary religious buildings use both artificial and natural light. The Regensburg Bishop opened the new church of Saint Francis in Regensburg-Burgweinting ${ }^{67}$ in May 2004. This was a new district needing a church. After some time for planning and a tender called in 1997 and won by Königs Architekten from Köln, a church was built. This church made an extremely interesting contribution to current religious architecture.

As you enter the church through a copper and glass door, you reach a small foyer from which you have an overwhelming view of the interior. The church interior consists of an ellipse with greenish brick walls, no windows and two big uneven grooves. This is an unparalleled event in current religious architecture. The ceiling is made of a Teflon layer allowing light to pass through, which is the main lighting source, together with the indirect light sources. The nave, of rectangular outer shape, possesses three big groups of benches and is a combination between the idea of path and the idea of the core altar. However, this cannot work out well: though the architects managed to avoid a central corridor, the predominant impression is that of a path towards the goal: the altar. The baptismal font is located at the altar side with some benches behind it. It should be expected that no further experiments or artisticartificial additions will be made at the central part of the church, apart from Robert Weber's proper decoration, from Grafing.

Another example worth showing here is that of the recently consecrated church of St. Florien, located in the Catholic part of the Munich-Riem Ecumenical Centre. The complex was completed last year and, in my opinion, it does not deserve 
the adjective ecumenical. The only thing shared by both communities which have built this centre in a huge plot, together with the Munich architect Florian Nagler is the tower. There are two of each: churches, sacristies, parish houses, children's areas, etc.

St. Florien's church main zone is the inner courtyard. As you walk through the double glass door, you find a wide rectangular and well-lit space with three windows. All of the works have been made by the Berliner artist Hella de Santarossa. The presbytery is surrounded by benches on three sides; the altar is at the centre and it receives zenithal lighting. The materials are very humble: clay and a stone slab. It has the shape of a compact rectangle and the clay makes it less monumental than it would appear at first. God's people are oriented towards the altar as the Lord's table, as well as towards the pulpit, which works as God's table in case of the Celebration of the Word. The cross is carved into the huge stained-glass window behind the altar. It can hardly be seen at midday with sunlight, though it will be perfectly visible in the evening when the church is lit up with artificial lighting. The altar piece is still the core for the community gathered there. The faithful are joined in the middle of the nave and the altar remains at the optical centre of the church, leading us to «our only Saviour, Jesus Christ, and to the single Eucharist of the Church» ${ }^{68}$.

\section{Liturgy}

In the theological sense, it is about the gathering of the community, about a double spiritual movement: from God to people and from people to God. Christ is present in the meeting of the community, in his consecrated representatives. in the Word and in the Eucharist ${ }^{69}$. This presence is materialised in the community space which needs not be a church. Many communities have churches which are presently too big and, for that reason, they are considering how to provide the new liturgy with a new form in the alreadyexisting churches. They are searching for a solution: how to express this scenario properly. The starting point for their considerations deals with the sources and basic topics of the liturgy. We are dealing with a communication event addressed to God, but happening among the community members. Communication in the liturgy framework is much more than a joint exchange: communication is an exchange with God.

The Communio-Räume (communion spaces) ${ }^{70}$ search for an integration of the church-path idea plus the Circumstantes ones. The point is to recall the basic idea of the II Vatican Council in a spatial configuration fostering the comprehension of the

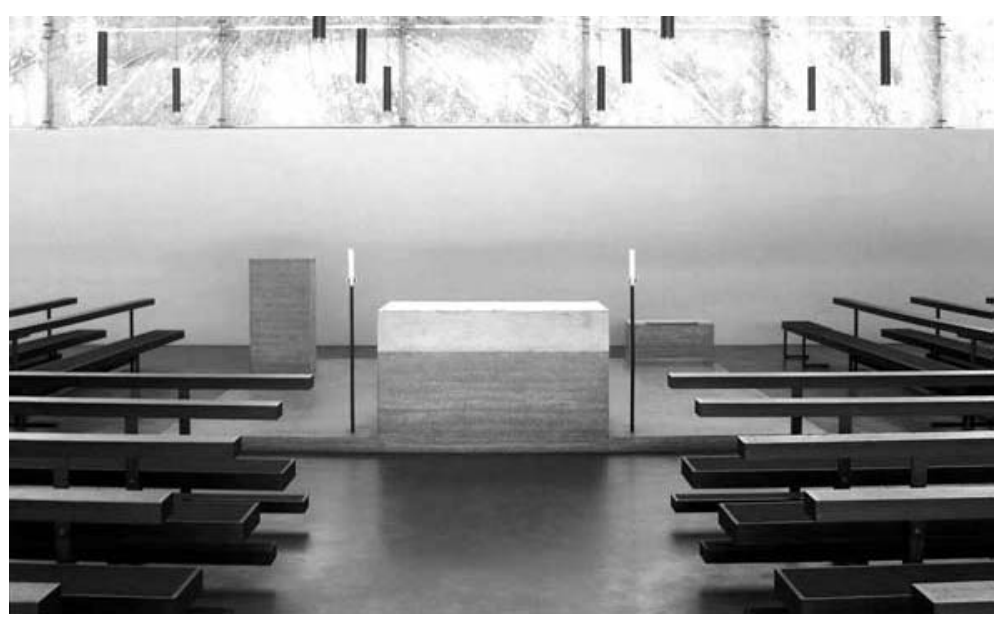

Allmann Scattler Wappner, iglesia del Corazón de Jesús (Herz-Jesu), Munich-Neuhausen, 1996/2000.

\section{Luz}

No sólo las catedrales de la Edad Media han hecho patente el significado de la luz en la arquitectura, sino que también en la construcción religiosa de hoy en día se emplea tanto de forma artificial como natural. En mayo de 2004, el obispo de Regensburg inauguró la nueva iglesia de San Francisco, en Regensburg-Burgweinting ${ }^{68}$. Al ser un barrio nuevo, hacía falta una nueva iglesia. Después de un tiempo de planificación y de un concurso que se convocó en el año 1997 y que ganó Königs Architekten, de Colonia, se construyó una iglesia que constituye una aportación extremadamente interesante para la arquitectura religiosa actual.

Cuando se entra en esta iglesia a través de una puerta de cobre y vidrio, se llega a un pequeño vestíbulo desde el cual la impresión del interior es abrumadora. El interior de la iglesia es una elipse con paredes de ladrillo ligeramente verdosas, sin ventanas, y dos grandes muescas de formas desiguales. Se trata de un acontecimiento en la arquitectura religiosa moderna que no tiene parangón. El techo se compone de una membrana de teflón que deja pasar la luz y es, junto con las fuentes de luz indirectas, la principal fuente de iluminación. La nave - que exteriormente presenta una forma rectangular - está provista de tres grandes grupos de bancos, y resulta una combinación entre la idea del camino y la del altar como centro. Pero en el fondo, esto no puede funcionar bien: aunque el arquitecto consigue evitar un pasillo central, predomina la impresión de un camino hacia una meta, el altar. La pila bautismal está emplazada en un lateral del altar, con algunos bancos detrás. Es de esperar que no se hagan más experimentos y añadidos artísticos-artificiales en la parte central de la iglesia, al margen de la acertada decoración de Robert Weber, de Grafing.

Otro ejemplo que quiero mostrar aquí es la recientemente consagrada iglesia de San Florián, situada en la parte católica del Centro Ecuménico 

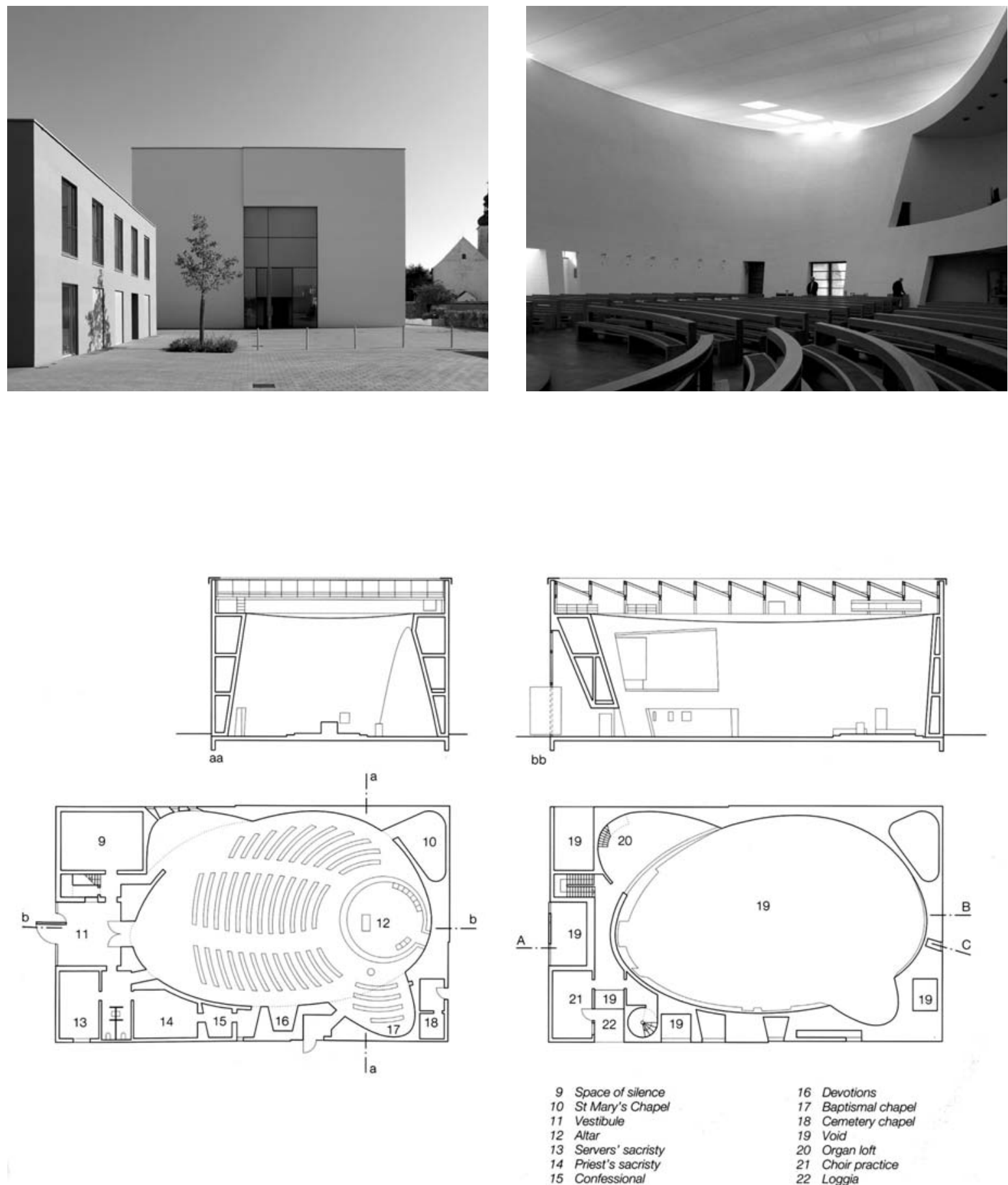

16 Devotions

17 Baptismal chape

18 Cemetery chapel

19 Void

20 Organ loft

21 Choir practice

15 Confessional

22 Loggia 
liturgy as a space for action, as a free space for the whole community, including the priest and for other services. Everything is addressed to the community here. The meaning of the celebration of the Last Supper with both parts becomes obvious: what is celebrated becomes present here. This new formalisation also offers the chance to re-structure churches which had become too big.

The purpose is to find a space for a precise event, for a different altar. Being a circular shape with a single centre, the various parts of the celebration, i.e., the Eucharist and the Celebration of the Word, would be just one again, regardless of their difference. For that reason, the ellipse is the right geometrical and mental shape containing, at least, two central foci: a place for the table of God's words and another one for the bread. The centre is empty and could be occupied by the Passover candle or a similar object, depending on the time of year. Thanks to this empty space in the middle, we could get closer to the transcendent God which cannot be taken in with images or symbols. Albert Gerhards calls this empty core the expectation space: the believers join there because they are expecting something that will take place in the still empty space ${ }^{71}$. Thus, they do not celebrate themselves. The empty core also expresses the expectation of the one who gives himself, the one who will live among the community. The empty core is a reference space.

And, finally, the liturgy is simultaneously a space for experimentation, a space to which human beings bring their personal experiences and where that also experience God and Jesus Christ. I will now show an illustrative example: Saint Anthony's church in Stuttgart, built by Hans Herkommer in 1932. The outside and the inside had to be refurbished in the 90s. Besides, it should be born in mind that the community is getting smaller and smaller. The local priest, who is also in charge of two other communities, is a very extroverted person. He took part in several meetings dealing with the issues and requirements of church-building in the late 20th century. There he came across the idea of a new type of meeting, he put it forward to his community and the possibility was widely discussed. The process ends with a clear and precise assignment: the community wishes to have a Communio-Räumetype space in the shape of an ellipse, something which had only been approached theoretically. The orientation of the typical church-path tried to be preserved. Günter Pfeifer, from Freiburg, a Professor at Darmstadt Technical University, won the tender and materialised the guidelines. He is friends with the artist Madeleine Dietz, who won a parallel tender for the same project. de Munich-Riem. El complejo fue terminado el año pasado y, según mi opinión, no merece la denominación de Centro Ecuménico. Lo único que tienen en común las dos comunidades que han construido aquí, en este gran solar, de forma conjunta con el arquitecto muniqués Florian Nagler, es la torre. Existen dos iglesias, dos sacristías, dos casas parroquiales, dos zonas infantiles, etc.

La zona principal de la iglesia católica San Florián es el patio interior. Cuando se entra por la doble puerta de vidrio, uno se encuentra en un espacio ancho, rectangular, iluminado, con tres ventanas. Todos son trabajos de la artista berlinesa Hella de Santarossa. El presbiterio está rodeado por bancos en tres de sus lados; el altar está en el centro, iluminado cenitalmente. Sus materiales son sencillísimos: barro y una losa de piedra. Su forma es un rectángulo compacto. El barro hace que la impresión sea menos monumental de lo que parece a primera vista. El pueblo de Dios está orientado hacia el altar como mesa del Señor, así como — en el caso de que se realice la «Celebración de la Palabra»— hacia el ambón como mesa de la Palabra de Dios. La cruz está labrada en el gran vitral que hay tras el altar; al mediodía y con iluminación solar, casi no será perceptible; en cambio, por las tardes, cuando se ilumine la iglesia con luz eléctrica, será perfectamente visible. El centro para la comunidad reunida sigue siendo la pieza del altar. Los fieles se concentran en el centro de la nave, y en el centro óptico del espacio de la iglesia está el altar, que nos dirige «a nuestro único Salvador, Jesucristo, y a la única Eucaristía de la Iglesia» ${ }^{69}$.

\section{Liturgia}

En el sentido teológico, se trata de la reunión de la comunidad, de un doble movimiento espiritual: de Dios hacia el hombre y del hombre hacia Él. La presencia de Cristo la encontramos en la comunidad reunida, en sus representantes consagrados, en la Palabra y en la Eucaristía ${ }^{70}$. Esta presencia se materializa en el espacio para la comunidad, que no necesariamente ha de ser una iglesia. Muchas comunidades tienen iglesias que en la actualidad son demasiado grandes, y por eso están pensando cómo se puede dar una nueva forma a la nueva liturgia en sus iglesias ya existentes. Están buscando una solución: cómo poder dar una expresión adecuada a esta situación.

El punto de partida para sus consideraciones son los orígenes y las cuestiones básicas de la liturgia. Nos encontramos ante un acontecimiento de comunicación que va dirigido hacia Dios, pero que también se produce entre los miembros la comunidad. La comunicación en el marco de la liturgia es mucho más que un intercambio conjunto: comunicación es intercambio con Dios.

La «Communio-Räume» (espacio de comunión) ${ }^{71}$ trata de buscar la integración entre la iglesia-camino y la idea de «Circumstantes». Con ello quiere retomar la idea básica del Concilio Vaticano II, en una configuración espacial que favorece la comprensión de la liturgia como espacio de acción, como espacio libre para toda una comunidad, incluido el sacerdote y los lectores, y para otros servicios. Aquí, todo está dirigido a la comunidad. 
Se hace patente lo que significa la celebración de la Última Cena con sus dos partes: aquí se hace presente lo que se está celebrando. Esta nueva formalización ofrece también la posibilidad de reestructurar iglesias que han llegado a ser demasiado grandes.

Se trata de buscar un espacio para un acontecimiento preciso, para un altar diferente. Tratándose de una forma circular que sólo tiene un punto central, las distintas partes de la celebración, es decir, la eucaristía y la celebración de la Palabra serían otra vez una sola, no se tendría en cuenta su diferencia. Por eso, la elipse es la figura geométrica y mental adecuada que contiene por lo menos dos focos centrales: un lugar para la mesa de la palabra de Dios y un lugar para la mesa del pan. El centro queda libre, y según la época del año, podría ser ocupado por el cirio pascual o alguna pieza similar. Con un espacio libre en el centro, nos aproximaríamos al Dios trascendente, no abarcable con imágenes o símbolos. Albert Gerhards llama a este centro libre «espacio de expectación»: los fieles se reúnen porque esperan algo, lo que va a acontecer en ese espacio todavía vacío ${ }^{72}$. De esta manera, ellos no se celebran a sí mismos. El centro libre es también la expresión de la expectación del que se da a sí mismo, el que va a habitar en la comunidad. El centro vacío es un espacio de referencia.

Y finalmente, la liturgia es, a la vez, un espacio para experimentar, un espacio en el cual los hombres traen sus experiencias personales, pero donde también experimentan a Dios y a Cristo. Mostraré un ejemplo que lo explica: la iglesia de San Antonio, en Stuttgart, construida en 1932 por Hans Herkommer. En los años noventa se hizo necesaria una renovación de su exterior y de su interior. Además, hay que tener en cuenta que la comunidad cada vez es más pequeña. El sacerdote del lugar, que también atiende a otras dos comunidades, es una persona muy abierta. Asiste a varias reuniones en las que se trata sobre las cuestiones y exigencias de la construcción de iglesias a finales del siglo XX. Allí conoce la idea de una forma nueva de reunión, la presenta a su comunidad y discute extensamente con ella esta posibilidad. El proceso finaliza en un concurso claro y preciso: la comunidad desea un espacio «Communio-Räume» en forma de elipse, una forma que hasta ahora sólo había sido tratada de forma teórica. Se intenta mantener la orientación de la «típica iglesia camino». Günter Pfeifer, de Freiburg, catedrático en la Universidad Técnica de Darmstadt, gana el concurso y pone en práctica las indicaciones. Congenia con la artista Madeleine Dietz, que gana otro concurso paralelo para el mismo proyecto.

Otra manera de actuar se refleja en las transformaciones de iglesias que se fundamentan en el principio de la así llamada «asamblea orientada» ${ }^{73}$. Esa idea de espacio asume las tres funciones básicas de la celebración de la misa. Se distingue entre:

- Proclamación. Durante la misa, una persona se dirige a muchos, es decir, a la congregación. Tenemos a un lector durante la primera y la segunda lecturas y a un sacerdote durante la proclamación del Evangelio y su

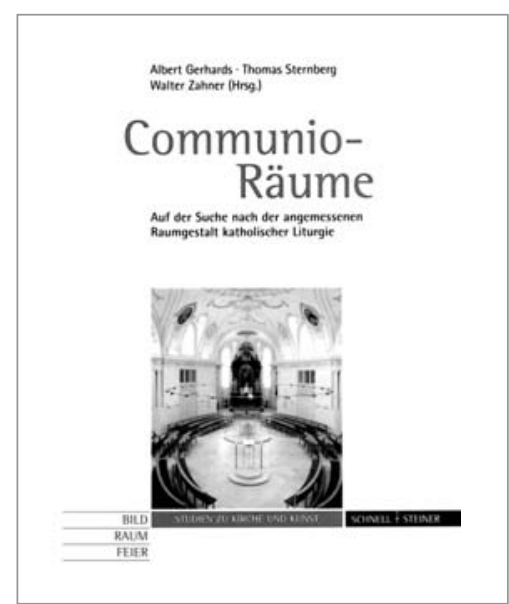

Albert Gehrards, Thomas Sternberg y Walter Zahner, portada del libro Communio-Raume, 2003

Another way of acting is reflected in the transformation of churches based on the socalled "oriented assembly» ${ }^{72}$ principle. This spatial idea assumes the three basic functions of the mass celebration, distinguishing among the following.

- Proclamation. During mass, a person is addressing an audience, that is, the congregation. There is a reader for the first and second readings and a priest during the Gospel proclamation and its interpretation. In order to obtain an optimal communication, the reader must be seen and heard by everybody: this is provided by the missal guidelines. The place of the proclamation has top importance inside the church $^{73}$. A scarcely studied location may cause the Word to sound like any other word.

- Prayer. During the joint prayer, the community and the celebrating priest make a clear decision: being face to face with God.

- Eucharist. The Eucharist is celebrated after the Liturgy of the Word. The best expression of Eucharist is the community surrounding the altar. Once again, I would like to refer to the idea of the Circumstantes, divulgated in the early 20th century by Dominikus Böhm and Martin Weber. Although the altar, as Jesus Christ's central sign, should be placed in the midst of the community, the congregation around the altar is by no means completed. The community experiences God's presence during the Eucharist and during the mystery. He is really present 


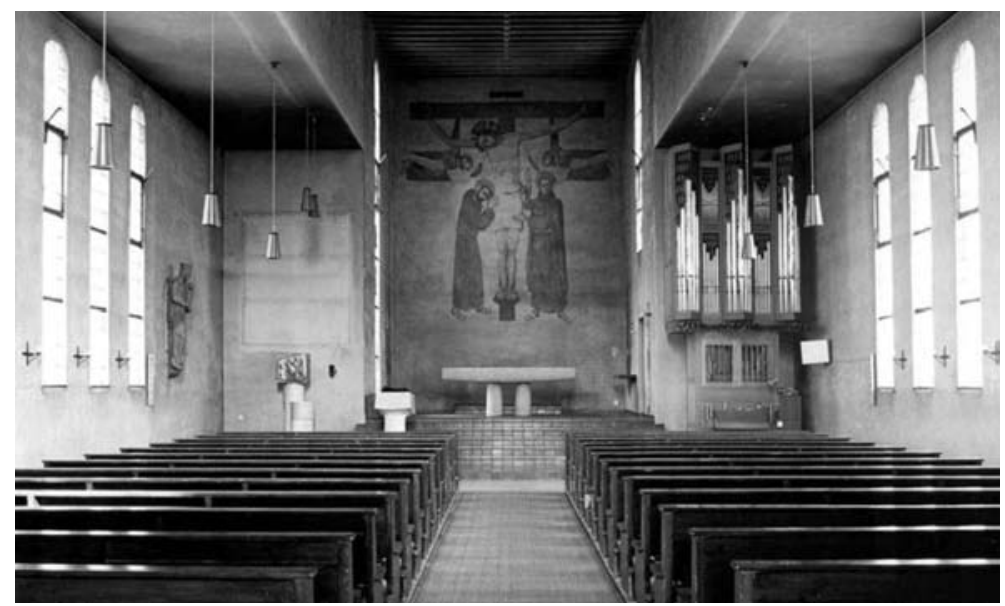

Hans Herkkomer, San Antonio, Stuttgart, 1932.
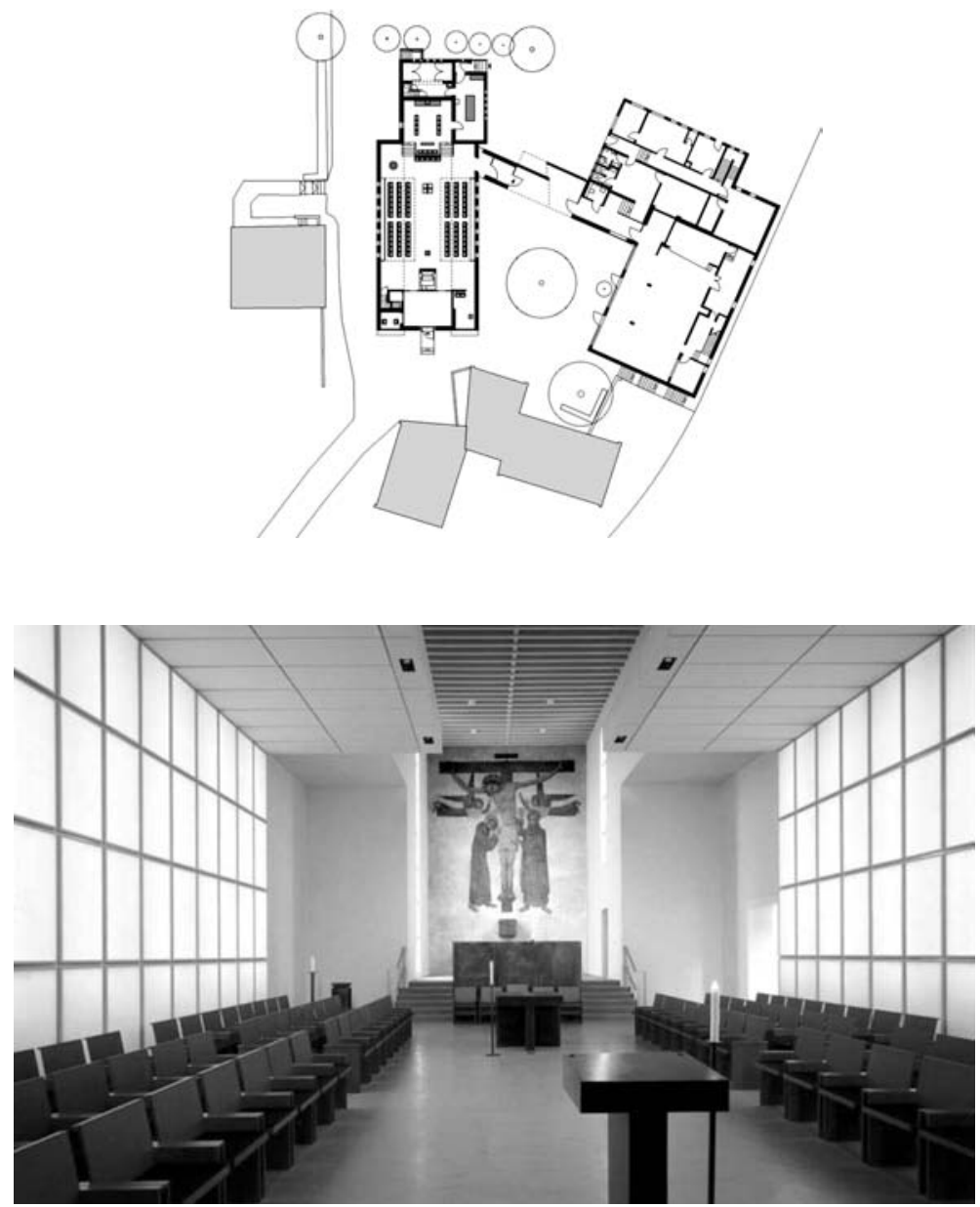

Günter Pfeiffer, remodelación de la iglesia San Antonio, Stuttgart, 1995/2006. 


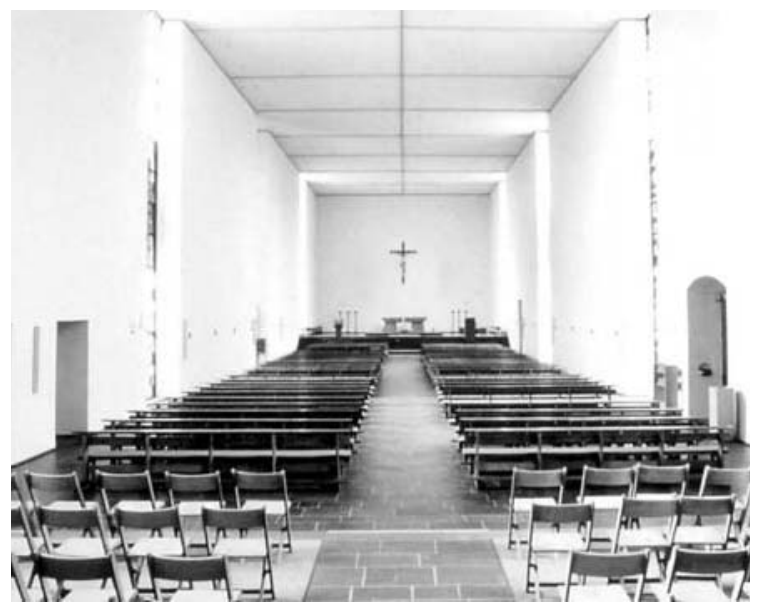

Rudolf Schwarz, San Alberto, Andernach, 1953.

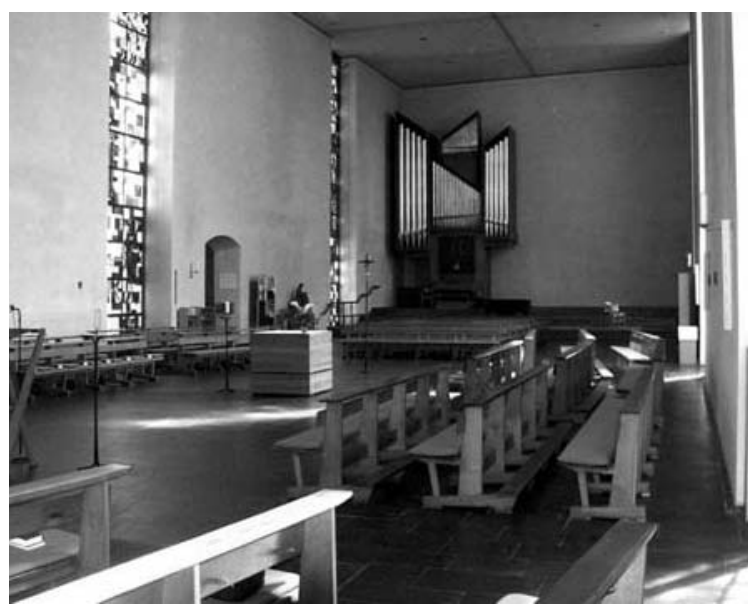

Maria Schwarz, Johannes Krämer y Albert Gerhards, remodelación de la iglesia de San Alberto, Andernach, 1998/2002. interpretación. Para conseguir una comunicación óptima, el lector tiene que ser visible y audible por todos: esto figura en las disposiciones del misal. Dentro de la iglesia, el lugar de la proclamación tiene la máxima importancia ${ }^{74}$. Un emplazamiento poco estudiado puede originar que la Palabra hablada parezca cualquier otra palabra.

- Oración. Durante la oración (conjunta), la comunidad - y con ella, el celebrante - toman una clara decisión: estar cara a cara con Dios.

- Eucaristía. Después de la liturgia de la Palabra, llega la celebración de la eucaristía. Ésta encuentra su mejor expresión en el hecho de que la comunidad se reúne alrededor del altar. Quiero hacer referencia en este momento, otra vez, a la idea de «Circumstantes», de la que hablaron, a principios del siglo XX, Dominikus Böhm y Martin Weber. Aunque el altar, como signo central de Cristo, debería tener su sitio en medio de la comunidad, de ninguna manera está terminada la congregación alrededor del altar. Durante la eucaristía, durante el misterio, la comunidad experimenta la presencia de Dios. Él está allí presente de veras, aunque no estamos todavía confrontados con su magnificencia celestial.

El último ejemplo es una adaptación muy consecuente con el concepto de «asamblea orientada». La historia del lugar donde está emplazada la iglesia parroquial de San Alberto, en Andernach, arranca en la Edad Media. La actual parroquia fue levantada en 1953 por el arquitecto de Colonia Rudolf Schwarz, a partir de las ruinas del monasterio anterior ${ }^{75}$. Schwarz construyó una iglesia clara y contemporánea de forma alargada. Hasta nuestros días, el espacio impresiona por su composición interior, extremadamente sencillo y sin ornamentación. Las paredes blancas representan apertura. El espacio no es lo más esencial: no es el edificio, sino la congregación y la celebración de las misas lo que llama la atención. there, although we are not yet faced with his heavenly magnificence.

The last example is a very consistent adaptation of the oriented assembly concept. The history of the place where Saint Albert's parish church in Andernach is situated starts in the Middle Ages. The current parish was erected by the Köln architect Rudolf Schwarz in 1953, from the ruins of the former monastery ${ }^{74}$. Schwarz built a contemporary clear and elongated church. The space is impressive due to its inner composition which is extremely simple and decor less. The white walls stand for openness. The space is not the most essential thing: it is not the building, but the congregation and celebration of mass which is striking.

The community is located along long rows of benches making a path. The architect intends to create openness, as well as a scatological orientation, and he refers to the issue of anonymity which is so visible in this building. He described it so: «the face to face look is missing here, nobody faces each other here, and everyone is looking at the front. The warm handshake is missing, the personal commitment to the others, and the thread of affectionate ties; because here everybody is alone in the midst of the group (...) the path shape leaves everybody alone within a group, hearts remain lonely. People cannot approach each other warmly because this scheme has no heart».

After checking this with the significant decrease in church attendance, the community contacted Rudolf Schwarz's widow, Maria Schwarz, from Köln, with the liturgical scientist Albert Gerhards, from Bonn, and the person 
responsible for the Trier bishopric, the engineer Johannes Krämer. It was not about discussing main changes in church-building, it was about debating contents.

The community wished to combine the idea of the path - with the goal of the Lord's death and resurrection - with the meeting around the altar as the table to which the community has been invited by the Lord. The solution was quite simple. The space underwent no transformations, even the same benches were used but in a different arrangement. Only the two central pieces of the liturgical facts (altar and pulpit) were designed again. Thus, in comparison to other church transformations, the financial costs were significantly reduced. The community has moved one step further through a thrilling process lasting several years, transforming this old church towards a lively and lasting Christianity ${ }^{75}$.

The parish priest Dechant Schultz described the community's first experiences: "There are many new things: facing each other, the glance which is not lost ahead along the space, but focuses on the opposite wall and those sitting there; the position of the altar which is no longer the only centre; having to turn around, first towards the pulpit and then towards the altar. All of this makes them learn again.

"Another thing is the progress: the community meets again, they feel again that a community is the group of people you belong with, the faith uniting them; there is less anonymity and more of a sense of community, the community is made by each of us, so now you can listen to the other, something that was completely lost; the liturgy is not a show on stage anymore, but a celebration of community. It has got closer; it is more visible and touchable. The common prayer has increased in intensity ${ }^{76}$.

A new path has opened to the community thanks to that, as well as the possibility to use their church space in a new manner.

\section{End and perspective}

Finally, I will present a couple of examples which seem to me significant for the future.

The first one is one of the few ecumenical centres built: Saint Mary Magdalene's church in Freiburg-Rieselfeld, made by the Kister, Scheitheuer \& Gross office from Köln and opened in July 200477. It was an interesting but difficult assignment that thrilled the architect Susanne Gross $^{78}$. It is conceived as an armoured concrete volume designed with plenty of folds and peaks. Practice will have to prove whether the basic idea of joining the rooms is really useful. The
La comunidad se sitúa en largas filas de bancos en forma de camino. El arquitecto pretende crear apertura y una orientación escatológica, a la vez que alude a la cuestión del anonimato que existe en cualquiera de estas iglesias y que es muy apreciable en esta construcción. Él lo describe de la siguiente manera: «Aquí falta la mirada 'cara a cara', aquí nadie mira al otro de frente, todos miran hacia adelante. Falta el intercambio cálido de manos, la entrega de hombre a hombre, la corriente de ataduras afectuosas, porque aquí cada uno está solo dentro del conjunto (...) La forma de camino deja a todos a solas dentro de un conjunto, el corazón se queda a solas. Los hombres no pueden acercarse unos a otros cordialmente, porque este esquema no tiene corazón» ${ }^{76}$.

Tras hacerse esto palpable al comprobar que la asistencia a la iglesia se había reducido significativamente, la comunidad se puso en contacto con la viuda de Rudolf Schwarz, la ingeniera Maria Schwarz, de Colonia, con el científico litúrgico Albert Gerhards, de Bonn, y con el responsable por parte del obispado de Trier, el ingeniero Johannes Krämer. No se trataba de discutir grandes cambios en la construcción de la iglesia, sino de discutir contenidos.

La comunidad deseaba combinar la idea del camino — cuya meta es la muerte y la resurrección del Señor-, con la reunión en torno al altar como mesa, a la cual ha sido invitada la comunidad por parte del Señor. La solución era bastante simple. El espacio no sufre transformaciones, incluso se siguen empleando los mismos bancos, pero ordenados de otra forma. Solamente los dos lugares centrales de los hechos litúrgicos, el altar y el ambón, fueron diseñados nuevamente. Así, en comparación con otras transformaciones de iglesias, los gastos financieros quedan significativamente reducidos. A través de un proceso emocionante que duró varios años, la comunidad ha dado otro paso adelante en este antiguo emplazamiento eclesial, en el sentido de un cristianismo vivo y duradero ${ }^{77}$.

El párroco, Dechant Schultz, describe las primeras experiencias de la comunidad: «Muchas cosas son nuevas: el verse frente a frente; la mirada que no se pierde por delante a lo largo del espacio, sino que se dirige a la pared de enfrente y a los que están allí sentados; la posición del altar, que ya no es claramente centro único; el tener que darse la vuelta, primero hacia el ambón y después hacia el altar. Todo esto hace que haya que aprender de nuevo.

»Por otro lado se encuentran los avances: la comunidad se vuelve a reunir, se siente nuevamente que la comunidad es el grupo de personas al que uno pertenece, la fe los une; existe menos anonimato y hay más sentimiento de comunidad, todos formamos la comunidad, de manera que uno puede oír al otro, algo que antes se había perdido completamente; la liturgia ya no es un 'espectáculo en un escenario', sino una celebración de la comunidad. Se ha acercado, es más visible y más palpable. La oración conjunta ha ganado intensidad» ${ }^{78}$.

Gracias a esto se ha abierto para la comunidad un camino nuevo, y la posibilidad de utilizar el espacio de su iglesia de una manera nueva. 


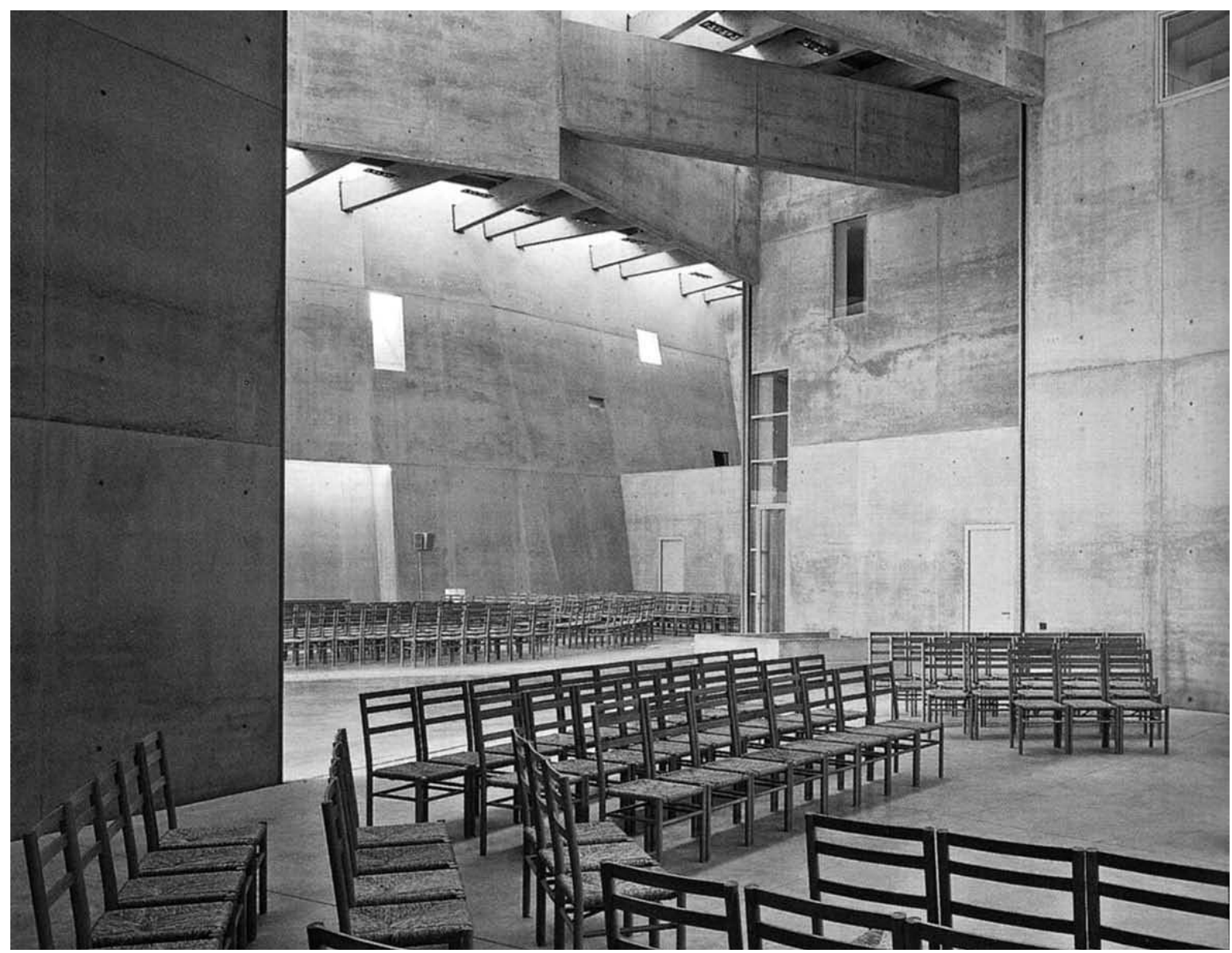

Kister, Scheithauer y Gross, Santa María Magdalena, Freiburg-Rieselfeld. 2002/04.
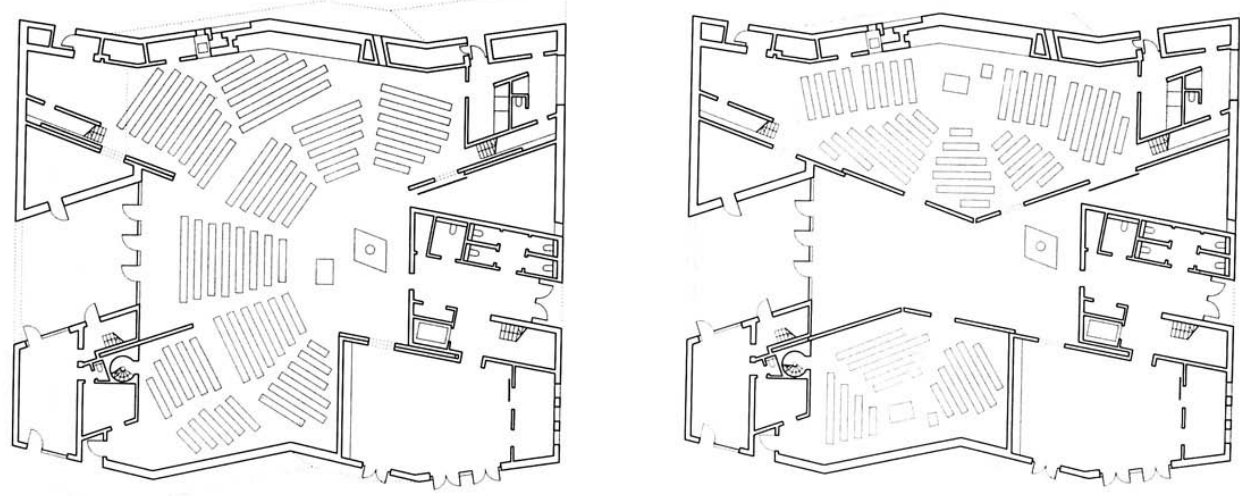
Protestant hall, which is smaller, can be attached to the Catholic one and the other way round, by means of a wide corridor and some sliding elements. The architect has designed the altar and the pulpit, together with the benches, which sets a good basis for their joint use. Both the Protestant and Catholic church space compositions are very similar: the Catholic area sits 250 believers, while the Protestant one sits around 100.

The space provides quite a nice impression, both as a whole and in its parts. Neither of the two zones achieved enough budget for the planned organ or for other artistic elements, though this also has a positive side. You need to get used to the different elements, such as the slanted armoured concrete walls, the central position of the altar and the pulpit, the main light source coming from the top, the wooden ceiling, the rather industrial lighting... In the end, they are convincing as a whole. The baptistery located in the foyer of the main entrance is already used jointly by both faiths, which creates a very positive general impression.

The political situation of the Church which is a difficult path towards ecumenism, with many hindrances, should not impact these types of projects. The future will tell whether the idea of building churches jointly in order to save construction and maintenance costs is feasible.

Finally, I go back to the beginning, to Rudolf Schwarz's controversy at the chapel of Rothenfels Castle. What is the use of this chapel, which is listed nowadays as a national monument? The idea of placing a big altar in the middle under a huge chandelier comes from the $80 \mathrm{~s}$ and it only satisfies the community gathering around the table wishing to share the wine and bread jointly. This requires that the members should know each other, which is certainly possible at the end of an assembly or meeting of friends of the castle However, for an ordinary community, that is, for people who only meet to give thanks or to celebrate mass, perhaps it would be too much. Within the framework of a conference which took place at that place in October 2005, titled «Maß und Gestalt. Perspektiven für Liturgie und Architektur» (Measurement and Shape. Perspectives for Liturgy and Architecture), several issues regarding the orientation of liturgical spaces were covered, those of Rudolf Schwarz in particular. A new arrangement of the already-mentioned oriented assembly was found, one evolving towards an open ring.

At the start of the celebration, the community gathers in the almost square chapel space, in the shape of an open U. Schwarz could call it chalice shape. That is, everyone gathers around

\section{FINAL Y PERSPECTIVA}

Finalmente, presentaré dos ejemplos que, en cierta manera, me parece que son significativos para el futuro.

Uno de ellos es uno de los pocos centros ecuménicos que se han construido: la iglesia de Santa María Magdalena en Freiburg-Rieselfeld, realizada por la oficina Kister, Scheitheuer y Gross, de Colonia, e inaugurada en julio de $2004^{79}$. Fue un encargo difícil pero interesante, que entusiasmó a la arquitecta Susanne Gross ${ }^{80}$. Está concebido como un volumen de hormigón armado, con un diseño con muchos pliegues y puntas. La práctica tendrá que demostrar si la idea básica de unir los habitáculos es realmente útil. El aula protestante, más pequeña, puede anexionarse al aula católica y viceversa, por medio de un amplio pasillo y por elementos deslizantes. El mismo diseño del altar y del ambón, así como el diseño de los bancos, son de la arquitecta, y una buena base para una utilización conjunta. La composición del espacio de la iglesia — tanto de la parte católica como de la protestante - es muy parecida: el ámbito católico tiene sitio para doscientos cincuenta fieles, y el protestante para unos cien.

La impresión que se recibe del espacio, en su totalidad y por separado, es bastante buena. En ambas zonas el presupuesto no alcanzó para el órgano proyectado ni tampoco para otros elementos artísticos, pero esto tiene su parte positiva. Las paredes exteriores de hormigón armado inclinadas, la colocación central del altar y del ambón, la fuente de luz principal que cae desde arriba, el techo de madera, la iluminación más bien industrial... a todos estos elementos hay que acostumbrarse, pero finalmente resultan convincentes en su conjunto. El baptisterio, situado en el vestíbulo de entrada principal, ya se utiliza de manera conjunta para ambas confesiones, lo que produce una impresión general muy buena.

La situación política de la Iglesia, que en lo ecuménico es un camino difícil y plagado de obstáculos, no puede influenciar a los proyectos de esta índole, aunque el futuro demostrará si la idea de erigir iglesias conjuntamente para ahorrar gastos de construcción y mantenimiento es posible.

Finalmente vuelvo al principio: a la controversia primera de Rudolf Schwarz en la capilla del castillo de Rothenfels. ¿Qué utilización se le puede dar a esta capilla, que hoy en día está catalogada como monumento nacional? La idea de poner un altar en el centro bajo una gran lámpara de araña proviene de los años ochenta, y sólo satisface a la comunidad que se reúne alrededor de la mesa y que quiere partir el pan y el vino conjuntamente. Esto exige que los distintos miembros se conozcan, lo cual es, sin lugar a dudas, posible al finalizar una asamblea o un encuentro de amigos del castillo. Pero para una comunidad normal, es decir, para personas que sólo se encuentran para dar gracias o para celebrar una misa, exige tal vez demasiado.

En el marco de una convención que se celebró en este lugar en octubre de 2005 bajo el título «Maß und Gestalt. Perspektiven für Liturgie und Architektur» (Medida y forma. Perspectivas para la liturgia y la arquitectura), se trataron los problemas de la orientación de los espacios litúrgicos, especialmente los de Rudolf Schwarz. Y se encontró una nueva disposición de la anteriormente mencionada «asamblea orientada», que evoluciona en un anillo abierto. 


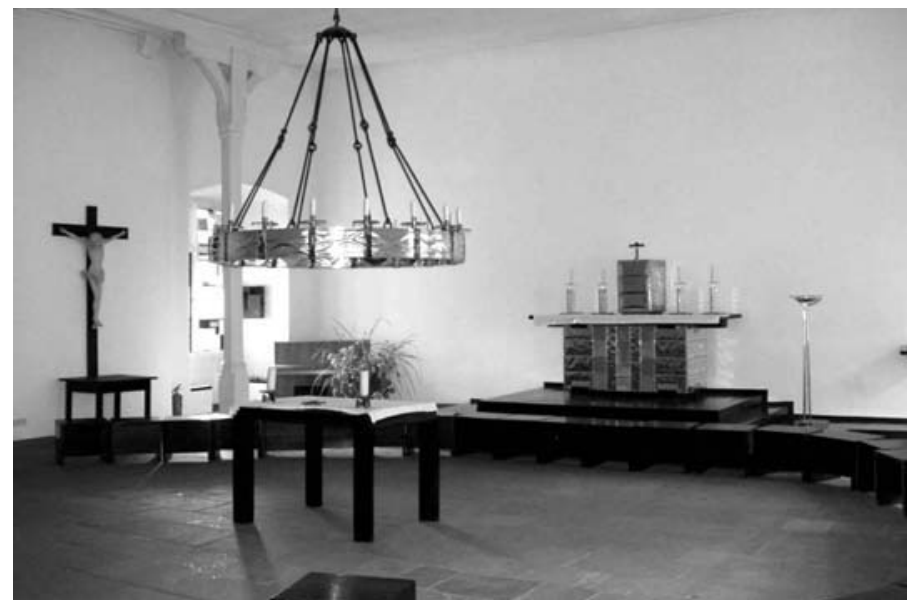

Reordenación litúrgica de la Capilla Permanente del castillo Rothenfels, 2005.

Al principio de la celebración, la comunidad se reúne en el espacio casi cuadrado de la capilla, formando una U abierta. Schwarz tal vez lo llamaría «forma de cáliz». Es decir, que todos los que están reunidos se disponen alrededor de espacio central, de momento todavía vacío, pero sin cerrarlo del todo. El sacerdote está sentado en medio de la comunidad, en el punto de cruce interior de la U. El altar sencillo, hecho de madera, no tiene ningún adorno, está vacío y situado cerca del centro de gravedad de la excéntrica «forma de cáliz» ${ }^{81}$. El cuarto lado se queda abierto y está dirigido hacia el altar, junto con el tabernáculo.

Al comenzar la celebración litúrgica, el sacerdote deposita el leccionario sobre la mesa del altar. El lector y la lectora lo cogen de allí. Ellos tienen un sitio al lado del celebrante. Para la lectura se dirigen hacia la comunidad, y son como su presencia física en la mesa de la Palabra. También el sacerdote lee el Evangelio del día desde ese lugar y después pone el libro sobre el altar antiguo, histórico. Seguidamente, se dirige otra vez a su sitio en medio de la comunidad. Celebra la eucaristía en este altar, manteniendo la vista por encima del círculo de la comunidad. La dirección exterior de la oración es espejo de la orientación interior hacia Dios. Para la comunión, el sacerdote se sitúa frente a la comunidad, y nuevamente se cierra el círculo. Para terminar, se celebra la presencia de Aquél que está presente en el sacramento, y el sacerdote se coloca nuevamente dentro de la comunidad y la bendice.

Pienso que esta forma es muy útil, e incluso me atrevo a decir que merece ser imitada. Con una forma figurativa, abre la comunidad hacia a Aquél a quien se dirigen las acciones de gracias por su venida y por su presencia entre nosotros. Creo que se adapta muy bien a las comunidades más pequeñas, pero también puede adaptarse a las comunidades parroquiales normales ${ }^{82}$. Y abre nuevos caminos para «el encuentro con Dios y con el hombre».

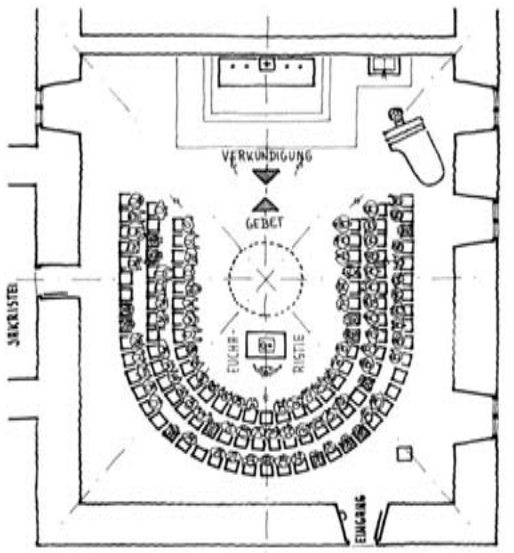

the central space, which is still empty, but not completely closed. The priest sits in the midst of the community at the $U$ inner crossing point. The simple wooden altar has no decoration; it is empty and located near the gravity centre of the eccentric chalice shape ${ }^{79}$. The fourth side remains open and is oriented towards the altar, together with the tabernacle.

As the liturgical celebration starts, the priest places the lectionarium upon the altar table. Both readers take it from there and are located next to the celebrating priest. They address the community during the reading and stand for their physical presence at the table of the Word. The priest also reads the day's Gospel from there and then places the book upon the old historical altar. Next, he moves to his place among the community. He celebrates the Eucharist at that altar, keeping his eyes above the community circle. The external direction of the prayer mirrors the interior orientation towards God. The priest stands before the community during the communion, and the circle is complete again. Finally, the presence of the one who is present in the sacrament is celebrated and the priest returns to the community with his blessing.

I believe that this is a very useful shape and I would dare say that it should be imitated. With a figurative shape, it opens the community to the one to whom the thanksgiving is offered for his coming and for his presence among us. I think that it is fit for small communities but it could also be adapted to ordinary parish communities $^{80}$, opening new ways for the meeting between God and people. 
Eine Ausstellung der DG Deutsche Gesellschaft für christliche Kunst, München, in Verbindung mit dem EKD-Institut für Kirchenbau und kirchliche Kunst der Gegenwart an der Philipps-Universität Marburg und dem Deutschen Liturgischen Institut, Trier.

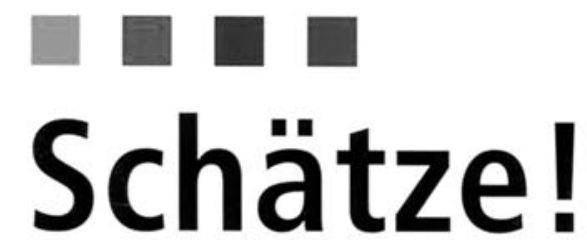

\section{Kirchen des 20. Jahrhunderts}

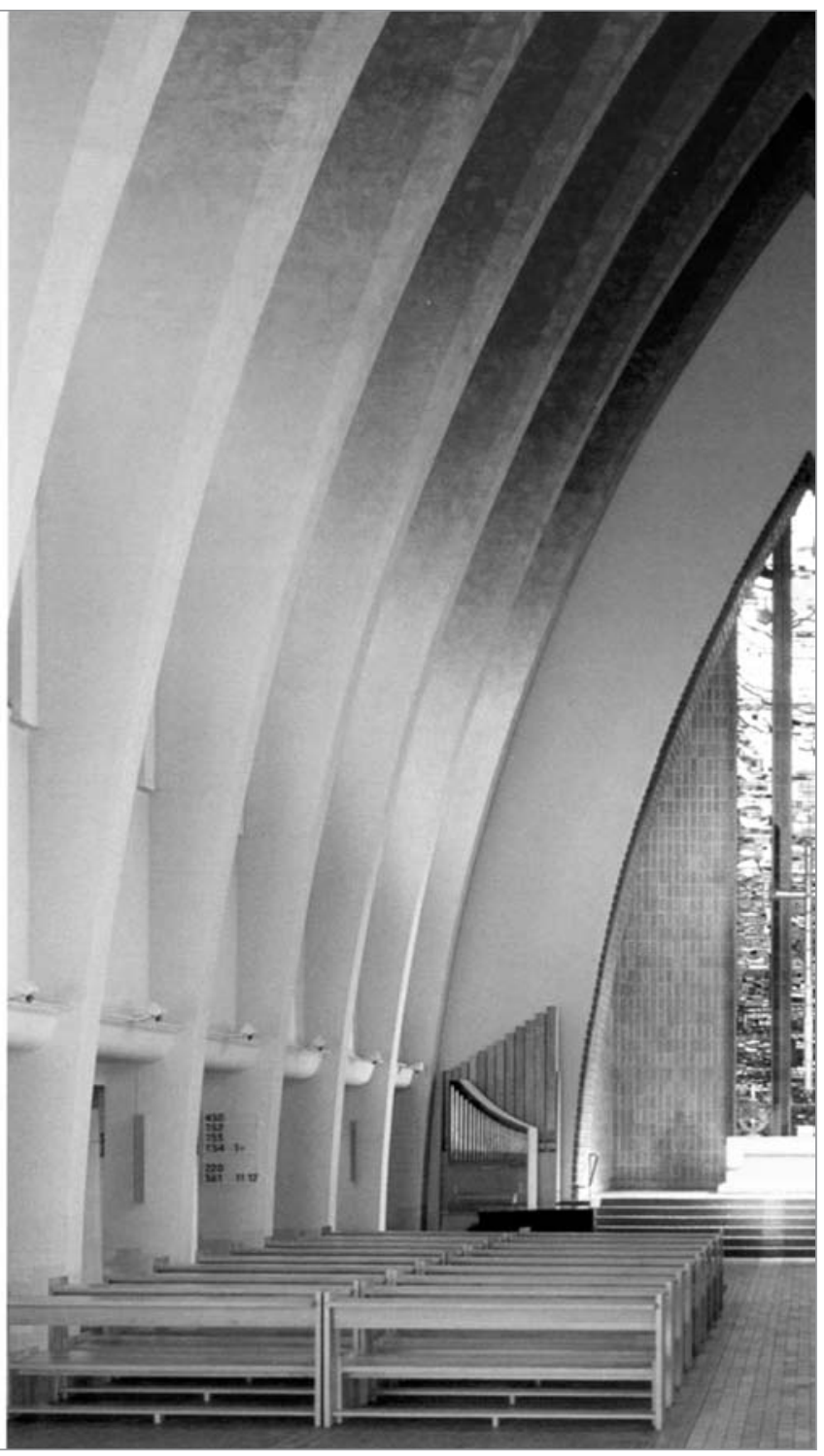

Portada del libro Schätze! Kirchen des 20. Jahrhunderts, 2007. 
Rudolf Schwarz, Kirchenbau. Welt vor der Schwelle, Regensburg, 2007. Facsímil de la primera edición de 1960 (Heidelberg). Editado por María Schwarz, Albert Gerhards y Josef Rüenauver:

2 Cf. Walter Zahner (ed.), Rudolf Schwarz. Baumeister der Neuen Gemeinde, Altenberge², 1998; asi como los catálogos de exposiciones: Conrad Lienhardt (ed.), «Rudolf Schwarz (1897-1961). Werk, Theorie, Rezeption», Regensburg, 1997; Wolfgang Pehnt/Hilde Strohl, «Bewohnte Bilder. Rudolf Schwarz. Architekt einer anderen Moderne», Ostfildern-Ruit, 1997.

3 Editado en Würzburg, Heidelberg y Salzburgo, respectivamente.

4 «Zum Geleit», en: Rudolf Schwarz, Kirchenbau. Welt vor der Schwelle, Heidelberg, 1960, sp.

Citado aqui según la traducción al alemán del prefacio «The Church Incarnate» (Chicago, 1938), publicado en: Fritz

Neumayer, Mies van der Rohe. Das Kunstlose Wort. Gedanken zur Baukunst, Berlin, 1986, pág. 394.

6 Maria Schwarz, «Vorwort» en: Rudolf Schwarz, Kirchenbau. Welt vor der Schwelle», Regensburg, 2007, pág. VII.

«Bauen als 'Aussage religiöser Poesie'. Ein teologischer Blick auf Rudolf Schwarz» (La construcción como 'expresión de la poesía religiosa'. Una mirada teológica a Rudolf Schwarz), en: Ibidem, pág. XIII-XIX; aqui XVII y XVIII.

8 Citado aqui según el texto básico de los obispos alemanes: Secretariado de la Conferencia Episcopal Alemana (ed.),

Leitlinien für den Bau und die Ausgestaltung von gottesdienstlichen Räumen, Bonn ${ }^{6}, 2002$, pág. 7. Aprobado por la Comisión Litúrgica de la Conferencia Episcopal Alemana el 25 de octubre de 1988.

9 «Vom Aufgang der Sonne. Orte für den Gottesdienst. Orte im Gottesdienst», Misa 40 (2006), pág. 65-67; aquí 65.

10 Cf. Hans Bernhard Meyer, Was Kirchenbau bedeutet, Freiburg, 1984.

"Cf. Albert Gerhards, «Die Aktualität der Avantgarde. Katholische Liturgie und Kirchenbau von 1900 bis 1950», en: Wolfgang Jean Stock (ed.), Europäischer Kirchenbau 1900-1950. Aufbruch zur Moderne, München y otros, 2006, pág. 70-89; aquí 73.

${ }_{12}$ Cf. Secretariado de la Conferencia Episcopal Alemana (ed.), Umnutzung von Kirchen. Beurteilungskriterien und Entscheidungshilfen. Bonn, 2003, pág. 10. Cf. especialmente el capitulo 2.

13 «Die Weihe der Kirche» $n^{o} 1$ y 2, en: Pontifikale IV, Trier, 1994, pág. 25.

${ }^{14}$ Cf. Winfried Haunerland, «Gottesdienst als Mass? Zum Kirchenraum als Feierraum», en: Monika Leisch-Kiesl y otros (eds.), Altarraum als Gemeinderaum. Umgestaltung bestehender Kirchen, Linz, 2004, pág. 43-50.

15 Cf. también las indicaciones cortas en: Albert Gerhards, Die Aktualität der Avantgarde, cit., pág. 70

${ }^{16}$ Cf. Albert Gerhards, "Heiliges Spiel: Kirchenmusik und Liturgie als Rivalinnen oder Verbündete?», en: Idem. (ed.), Kirchenmusik im 20. Jahrhundert. Erbe und Auftrag, Münster, 2005, pág. 29-38; así como Wolfgang Reiffer, «Das Motu proprio Pius X. Und seine Auswirkungen bis zum Zweiten Vatikanischen Konzil», en: Idem., pág. 77-97.

17 Este entendimiento de la liturgia como fuente lo encontramos también en la constitución litúrgica del Concilio Vaticano II (cf. Sacrosanctum Concilium, art. 10).

18 Citado por Willy Weyres, Neue Kirchen im Erzbistum Köln, 1945-1956, Düsseldorf, 1957, pág. 27.

${ }_{19}$ Cf. Siegfried Giedion, Walter Gropius. Mensch und Werk, Stuttgart, 1954, especialmente pág. 26, así como: Winfried Nerdinger, Walter Gropius, Berlin, 1985, especialmente pág. 9-11, y Reginald R. Isaacs, Walter Gropius. Der Mensch und sein Werk (tomo I), Frankfurt, 1985, pág. 105-109.

${ }^{20}$ Cf. Angelika Thiekötter y otros, Kristallisationen, Splitterungen. Bruno Taut Glashaus, Basel y otros, 1993.

${ }_{21}$ Cf. Jüngst Wolfram, «Deutsche Werkbund-Ausstellung Köln 1914», en: Winfried Nerdinger (ed.), 100 Jahre Deutscher Werkbund 1907/2007, München, 2007, pág. 65.

${ }_{22}$ Cf. con mi articulo «Auf der Suche nach einem zeitgemäßen Ort der Liturgie. Der Kirchenbau in Frankreich im 20. Jahrhundert» (en imprenta).

${ }^{23}$ Cf. Wolfgang Jean Stock, Europäischer Kirchenbau 1900-1950, cit., pág. 32-39 (sobre la iglesia de Steinhof, de Otto Wagner) y 74 ss. (sobre St. Nikolaus en Essen, de Carl Moritz).

${ }^{24}$ Esto no lo trataremos más aquí. Para ello hay que utilizar la literatura pertinente: Otto Bartning, Vom Raum der Kirche, Bramsche, 1958 (con textos a partir de 1909); Gerhard Langmaack, Evangelischer Kirchenbau im 19. und 20. Jahrhundert. Geschichte. Dokumentation. Synopse, Kassel, 1971; así como los dos tomos de Wolfgang Jean Stock, Europäischer Kirchenbau 1900-1950 y Europäischer Kirchenbau 1950-2000, München, 2004, con sus articulos, entre otros, el de Horst Schwebel.

${ }_{25}$ Cf. Conrad Lienhardt (ed.), Emil Steffann 1899-1968, Werk, Theorie, Wirkung, Regensburg, 1999

26 Johannes van Acken, Christozentrische Kirchenkunst. Ein Entwurf zum liturgischen Gesamtkunstwerk, Gladbeck, 1922, pág. II.

${ }^{27}$ Cf. Johannes Heimbach, Quellen menschlichen Seins und Bauens offen halten. Der Kirchenbaumeister Emil Steffann (1899-1968), Altenberge, 1995, pág. 26-40.

${ }_{28}$ Aloys Goergen, «Rothenfels und die Folgen», en: Hans Wichmann (ed.), Kirche heute. Architektur und Gerät. Süddeutscher Raum, München, 1984, pág. 12-18; aqui 12.

${ }_{29}$ Cf. una exposición más amplia en: Walter Zahner, Rudolf Schwarz, cit. pág. 50-187.

${ }^{30}$ Cf. su escrito Vom Geist der Liturgie, y además: Hanna-Barbara Gerl, Romano Guardini 1885-1968. Leben und Werk, Mainz, 1985 (ha sido reeditado varias veces).

31 Cf. Casiano Floristán Samanés, «Die Liturgie, Ort der Erziehung zum Glauben», Concilium, 20 (1984), pág. $316-323$ (aqui indicación 6).

32 Freiburg, 1918. Desde entonces, se han realizado muchas reediciones. Primera edición española: Araluce, Barcelona, 1933.

${ }_{33}$ Librería y Tipografia Católica Pontificia, Barcelona, 1918. A partir de 1940 (2ª edición), las siguientes ediciones las realizó la editorial Casulleras.

34 Burg Rothenfels-am-Main, 1923.

35 Inicialmente apareció en dos fascículos (primera edición, Würzburg, 1922) y después, resumido (Burg Rothenfels-am-Main, 1923). Primera edición española: Editorial Litúrgica Española, Barcelona, 1957, aunque existe una edición anterior en castellano: Surco, Buenos Aires, 1946

36 Romano Guardini, Liturgische Bildung, cit., pág. 13 y 30.

${ }^{37}$ Cf. Walter Zahner, Rudolf Schwarz, cit.

38 Rudolf Schwarz, "Die neue Burg», en: Ludwig Neundörfer et al., Burg Rothenfels 1919/1929, Burg Rothenfels, 1929, pág. 27-35; aqui 28 .

${ }^{39}$ Idem., Kirchenbau. Welt vor der Schwelle, Heidelberg, 1960, pág. 37 y 41.

40 Cf. Herbert Muck, «Liturgie und Kirchenraum», Bibel und Liturgie, 38 (1964/65), pág. 413-419; aqui 414.

${ }^{41}$ Rudolf Schwarz, Vom Bau der Kirche, Würzburg, 1938 (Salzburg $\left.{ }^{3}, 1999\right)$ ) pág. 25.

42 Cf. Walter Zahner, Rudolf Schwarz, cit., pág. 193-220.
Rudolf Schwarz, «Kirchenbau. Welt vor der Schwelle», Regensburg. 2007. Facsimile of the first edition from 1960 (Heidelberg). Edited by Maria Schwarz, Albert Gerhards \& Josef Rüenauve.

Cf. Walter Zahner (ed.), "Rudolf Schwarz. Baumeister der neuen Gemeinde», Altenberge 2,1998 ; as well as the exhibition catalogues: Conrad Lienhardt (ed.), «Rudolf Schwarz (1897-1961). Werk, Theorie, Rezeption, Regensburg, 1997; Wolfgang Pehnt/Hilde Strohl, «Bewohnte Bilder. Rudo Schwarz. Architekt einer anderen Moderne», Ostfildern-Ruit, 1997.

Edited in Würzburg, Heidelberg and Salzburg, respectively.
"Zum Geleit», in: RudolfSchwarz, «Kirchenbau. Welt vor der Schwelle», "Zum Geleit», in:
Heidelberg, $1960, s p$.

Heidelberg, 1960, sp.

Quoted here according to the German translation of the preface «The Church Incarnate» (Chicago, 1938), published in: Fritz Neumayer, «Mies Van der Rohe. Das Kunstlose Wort. Gedanken zur Baukunst), Berlin, 1986 ,
pag. 394. pag. 394.

Maria Schwarz, «Vorwort» in: Rudolf
der Schwelle», Regensburg, 2007, pag. VII.

Whelle», Regensburg, 2007, pag. VII. «Bauen als Aussage religiöser Poesie. Ein teologis her

Quar», in: Ibidem, pag. XIII-XIX, here XVII y XVIII.

Quoted here accoraing to the German bishops basic text: German Episcopal Conference Secretariatled.), "Leitlinien fur den Bau und di Ausgestattung von gottesaienstlichen Raumenn, Bonn, 2002, pag. 7. Approved by the Liturgical
October 1988 .

Corte für den Gottesdienst Orte in Gottesdienst), Mass 40 (2006), pag. 65-67; here 65 .

Cf. Hans Bernhard Mever, «Was Kirchenbau bedeutet》, Freiburg 1984.

Cf. Hans Bernhard Mever, «Was Kirchenbau bedeutet》, Freiburg, 1984. "Cf. Albert Gerhards, "Die Aktualität der Avantgarde. Katholische
Liturgie und Kirchenbau von 1900 bis 1950», in: Wolfgang Jean Stock (ed.),

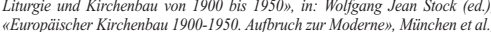
"Europäischer Kirchenbau

2006, pag. 70-89; here 73.
Cf. Secretariat of the German Episcopal Conference (ed.), «Umuutzung von Kirchen. Beurteilungskriterien und Entscheidungshilfen». Bonn, 2003, pag. 10. Cf. Particularly chapter 2.

Cf. Particularly chapter 2.
«Die Weihe der Kirche» $n^{\circ} 1$ and 2 , in: «Pontifikale IV》, Trier, 1994, pag 25. "Die Weihe der Kirche»n I and 2, in: «Pontifikale IN", Trier, 1994, pag. 25. als Feierraum", in: Monika Leisch-Kiesl et al. (eds.), "Altarraum als

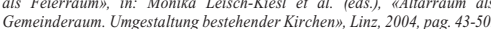
Cf. Also the short remarks in: Albert Gerhards, «Die Aktualität der vantgardes, quote, pag. 70.

Cf. Albert Gerhards, «Heiliges Spiel: Kirchenmusik und Liturgie als Rivalinnen oder Verbündete?», in: Idem. (ed.), "Kirchenmusik im 20. Jahrhundert. Erbe und Auftrag», Münster, 2005, pag. 29-38; as well a Wolfgang Reiffer, «Das Motu proprio Pius X. Und seine Auswirkungen bis zum zweiten Vatikanischen Konzill, in: Idem., pag. 77-97.

17 This understanding of the liturgy as source is also found in the liturgical Constitution of the II Vatican Council (cf. «Sacrosanctum Concilium», art. 10 . Quoted by Willy Weyres, «Neue Kirchen im Erzbistum Köln, 1945-1956», Düsseldorf, 1957, pag. 27.

Cf. Siegfried Giedion, «Walter Gropius. Mensch und Werk», Stuttgart, 1954, particularly pag. 26, as well as: Winfried Nerdinger, «Walter Gropius», Berlin, 1985, particularly pag. 9-11, and Reginald R. Isaacs, «Walter Gropius. Der Mensch und sein Werk» (vol. I), Frankfurt, 1985, pag. 105-109. ${ }_{20}$ Cf. Angelika Thiekötter et al., "Kristallisationen, Splitterungen. Bruno Tau Glashaus», Basel et al., 1993.

Cf. Jüngst Wolfram, "Deutsche Werkbund-Ausstellung Köln 1914», in Winfried Nerdinger (ed.), "100 Jahre Deutscher Werkbund 1907/2007», Munich, 2007, pag. 65

Cf. With my paper «Auf der Suche nach einem zeitgemäßen Ort der Liturgie. Der Kirchenbau in Frankreich im 20. Jahrhundert) (on the press). Cf. Wolfgang Jean Stock, «Europäischer Kirchenbau 1900-1950», quote. pag. 32-39 (about the Steinhof church by Otto Wagner) and 74 following (about St. Nikolaus in Essen by Carl Moritz).

${ }_{24}$ This will not be further covered here. The appropriate literature must be used for that purpose: Otto Bartning, «Vom Raum der Kirche», Bramsche, 1958 (with texts from 1909); Gerhard Langmaack, «Evangelischer Kirchenbau im 19. und 20. Jahrhundert. Geschichte. Dokumentation. Synopse», Kassel, 1971; as well as the two volumes by Wolfgang Jean Stock, «Europäischer Kirchenbau 1900-1950" and "Europäischer Kirchenbau 1950-2000 ${ }_{25}$ Cf. Conrad Lienhardt (ed.). «Emil Steffann 1899-1968, Werk. Theorie,

${ }^{25}$ Cf. Conrad Lienhardt (ed.), «Emil Steffann 1899-1968, Werk, Theorie,
Wirkung", Regensburg, 1999. 26 Johannes van Acken, "Christozentrische Kirchenkunst. Ein Entwurf zum liturgischen Gesamtkunstwerk», Gladbeck, 1922, pag. II. Cf. Johannes Heimbach, "Quellen menschlichen Seins und Bauens offen halten. Der Kirchenbaumeister Emil Steffann (1899-1968)», Altenberge, 1995,
pag. 26-40.

${ }^{28}$ Aloys Goergen, «Rothenfels und die Folgen», in: Hans Wichmann (ed.) "Kirche heute. Architektur und Gerät. Süddeutscher Raum》, München,
1984, pag. 12-18; here 12.

Cf. A wider explanation in: Walter Zahner, "Rudolf Schwarz», quote pag. 50-187.

Cf. his writing "Vom Geist der Liturgie», and also: Hanna-Barbar Gerl, «Romano Guardini

(released several times)

Cf. Casiano Floristán Samanés, "Die Liturgie, Ort der Erziehung zum Glauben), Concilium, 20 (1984), pag. $316-323$ (indication $n^{0} 6$ here).

Freiburg, 1918. Many re-releases since; first Spanish edition: Araluce,

Barcelona, 1933.

Librería y Tipografia Católica Pontificia, Barcelona, 1918

Burg Rothenfels-am-Main, 1923

It was initially published in two issues (first edition, Würzburg, 1922) and, later, summarised (Burg Rothenfels-am-Main, 1923). First Spanish edition: Editorial Litúrgica Española, Barcelona,

Spanish edition: Surco, Buenos Aires, 1946. Romano Guardini, "Liturgische Bildung»,
Cf. Walter Zahner, «Rudolf Schwarz», quote.

Rudolf Schwarz, «Die neue Burg", in: Ludwig Neundörfer et al., «Bur Rothenfels 1919/1929», Burg Rothenfels, 1929, pag. 27-35; here 28. ${ }_{39}$ Idem., «Kirchenbau. Welt vor der Schwelle», Heidelberg, 1960, pag. 37 39 Iden
and 41 .
Cf.

${ }^{40}$ Cf. Herbert Muck, "Liturgie und Kirchenraum», Bibel und Liturgie, 38 (1964/65), pag. 413-419; here 414. 
41 Rudolf Schwarz, «Vom Bau der Kirche», Würzburg, 1938 (Salzburg". 1999), pag. 25

Cf. Walter Zahner, «Rudolf Schwarz», quote, pag. 193-220

Rudolf Schwarz, "Kirchenbau. Welt vor der Schwelle», Heidelbers. 1960, pag. 16

Romano Guardini, "Die neuerbaute Fronleichnamkirche in Aachen Die Schildgenossen, 11 (1931), pag. 266-268.

Cf. Rudolf Schwarz, "Kirchenbau», quote, pag. 24.

Cf. Idem., "Vom Bau der Kirche», quote (pictures) Rudolf Schwarz, "Das Anliegen der Baukunst), Mensch und Raum, 67 (1952), pag. 60-71; here 65 .

. Des signes et des lieux dans l'oeuvre de Roman Guardini), Chronique d'Art sacré, 37-40 (1994), 41 and 42 (1995).

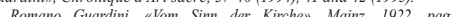
Romano Guardini, "Vom Sinn der Kirches, Mainz, 1922, pag. Kirche heute Architeltur und Gerät. Sïddeutscher Raumin München. 1984, pag 12-18: here 16

1984, pag. 12-18; here 16. Böhmy, Munich Z Zuj, Herber

${ }_{2}$ G.E. Kidder Smith, «Moderne Architektur in Europa», Munich, 1964 pag. 32 .

You may read about this architect: «Quellen des menschlichen Seins und Bauen Con . Werk. Theorie. Wirkung,

ag. 253 .

Cf. Emil Steffanns gleichnamigen Vortrag aus dem Jahr 1963n, in. Gisbent Hülsmann and Manfred Sundermann. "Emil Steffann», Düsseldorf? 1981 , pas 102

${ }_{56}^{102 .}$ Cf. Birgit-Verena Karnapp, «Kirchen. München und Umgebung nac 1945», Munich/Berlin, 1996, pag. 53-55.

77 This is the title of a paper written by him (Freiburg, 1981).

${ }_{8}$ According to the Benedictine monk Angelus A. Häussling, «Von Sinn der iturgie», Schriften der Katolischen Akademie in Bavern, 140 (1991). pag. 118-130; here 118.

Voz "Liturgia" in: Rupert Berger, «Neues Pastoralliturgiesche Handlexikon», Freiburg, 1999, pag. 309-311; here 310.

"Sacrosanctum Concilium», art. 7 and 10 .

Cf. Walter Zahner, «Maison de Dieu Maison, de l'homme», Techniques architecture, 459 (2002), pag. 68-75; here 68 .

2 Edited by the Secretariat of the German Episcopal Conference, Bonn, 2003. ${ }^{3}$ Ibidem, pag. 14.

Cf. The exhibition catalogue: Walter Zahner (ed.), «Schätze! Kirchen des 20. Jahrhunderts», Lautertal, 2007 (with some important articles, among them by Albert Gerhards or Maria Schwarz.

Quoted according to Meinrad Franz, "Zur Geschichte von St. Juda Thaddäus», in: Sa., "Katholisches Gemeindezentrum St. Judas Thaddäus, Karlsruhe-Neuret), Lindenberg, 1998, pag. 1 and following; here 2.

Cf. Walter Zahner, «Katholisches Gemeindezentrum St. Judas Thaddäus, Karlsruhe-Neureut», in: Conrad Lienhardt (ed.), "Ottokar Uhl. Werk, Theorie Prespektiven), Regensburg, 2000, pag. 115-136; and Thomas Mayman «Architektonische Planung: Partizipation und Reduktion. Ottokar Uhl und der Kirchenbau St. Judas Thaddäus in Karlsruhe», in: Nadine Baumann/Martin Stuflesser (eds.), «Das Geheimnis lässt uns künden. Liturgie zwischen Wissenschaf und pastoraler Wirklichkeit), Münster; 2005, pag. 197-209.

"Cf. Wilhelm Kücker, «Pfarrzentrum St. Franziskus, Regensburg», in: Ingeborg Flagge et al. (eds.), «DAM Jahrbuch 2003», Munich, 2003, pag. 66 75; and Walter Zahner, «Eglise Saint-Francois, Ratisbonne-Burgweintin Allemagne», L'architecture d'aujourd'hui, 356 (2005), pag. 70-75.

${ }_{8}$ Cf. «Das Pontifikale zur Altarweihe, hier zitiert nach Stichwort: Altar in: Rupert Berger, «Neues Pastoralliturgisches Handlexikon», Freiburg. 1999, pag. 15-18; here 17.

"Cf. «Sacrosanctum Concilium», art. 7 .

Cf. More extensively: Albert Gerhards/Thomas Sternberg/Walte Zahner (eds.), "Communio-Räume. Auf der suche nach der angemessenen

Cf. Albert Gerhards, «In der Mitte der Versammlung», Trier, 2001.

Cf. Johannes Krämer/Walter Zahner, «Realizzazioni di spazi liturgic Germania. Anallst liturgicae architettonica», in: Goffredo Bosell ed.) "Spazio liturgico e orientamento» (Atit del IV Convegno Liturgic Internazionale, Bose 1-3 gitugno 2006), Bose, 2007, pag. 61-83.

(Ati el IIT Convegno liturgico internazionale, Bose 2-4 giugno 2005), Bose

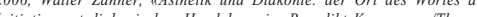
Initialionsort Ziskonischen Handelns,, in. Benedikt Kranemann/Thomas Freiburg, 2006, pag. 261-270.

Cf. Rudolf Schwarz, "Kirchenbau», quote, pag. 147-154

Cf. www.sankt-albert.de/raum (access on 2/10/2006), with the title «Ein Comeinde-Prozess: Innenraumgestaltung der Pfarrkirche St. Albert (19982002)" a thorough explanation is made about the joint work between

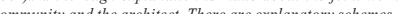

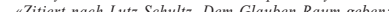

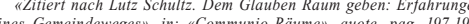
eines Ge 198

Cf Walter Zahner uMaria Magdalena Katholische und evangelische Kirche in Freiburg-Rieselfeldy, Lindenberg 2006; other literary references may be in Freiburg-Rieselfeld", Lindenberg, 2006; other literary references may be seen in: Matthias Ludwig and Reinhard Mawick (eds.), "Gottes neue Hauser: Kirchenbau

pag. 124-129.

Cf. Christin Feireiss, «Vorwort» in: Christin Feireiss and Hans-Jürgen Comerell (eds.), «Kister Scheithauer Gross. Doppelkirche für zwel Konfessionen», Berlin, 2004, pag. 4

Cf. Burkhard Cramer, "Der offene Ring. Erfahrungen bei eine Eucharistiefeier auf Burg Rothenfels», Gottesdienst, 40 (2006), pag. 20ss.; here 20.

${ }_{80}$ Cf. Walter Zahner, "Liturgie zwischen Geist und Form», in: Conrad Lienhardt, "Sakralraum im Umbruch. Kirchenbau der Katholischen Kirche in Oberösterreich seit 1948», Regensburg, 2004, pag. 18.
${ }^{43}$ Rudolf Schwarz, «Kirchenbau. Welt vor der Schwelle», Heidelberg, 1960, pág. 16.

${ }^{44}$ Romano Guardini, «Die neuerbaute Fronleichnamkirche in Aachen», Die Schildgenossen, 11 (1931), pág. 266-268.

45 Cf. Rudolf Schwarz, "Kirchenbau», cit., pág. 24.

46 Cf. Idem., «Vom Bau der Kirche», cit. (imágenes).

47 Rudolf Schwarz, «Das Anliegen der Baukunst», Mensch und Raum, 67 (1952), pág. 60-71; aquí 65.

48 Cf. Frédéric Debuyst, «Des signes et des lieux dans l'oeuvre de Romano Guardini», Chronique d'Art sacré, 37, 38, 39, 40 (1994), 41 y 42 (1995).

49 Romano Guardini, «Vom Sinn der Kirche», Mainz, 1922, pág. I.

50 Aloys Goergen, «Rothenfels und die Folgen», en: Hans Wichmann (ed.), «Kirche heute. Architektur und Gerät. Süddeutscher Raum», München, 1984, pág. 12-18; aqui 16.

${ }^{51}$ Cf. August Hoff, Herbert Mucky Raimund Thoma, «Dominikus Böhm», München/Zürich, 1962.

52 G.E. Kidder Smith, «Moderne Architektur in Europa», München, 1964, pág. 32.

53 Sobre este arquitecto puede verse: «Quellen des menschlichen Seins und Bauens offen halten. Der Kirchenbaumeister Emil Steffann (1899-1968)», Altenberge, 1995; Conrad Lienhardt (ed.), «Emil Steffann (1899-1968). Werk. Theorie. Wirkung», Regensburg, 1999.

55 Cf. Wolfgang Pehnt, «Der Anfang der Bescheidenheit», München, 1983, pág. 253.

${ }^{56}$ Cf. «Emil Steffanns gleichnamigen Vortrag aus dem Jahr 1963», en: Gisbert Hülsmann y Manfred Sundermann, «Emil Steffann», Düsseldorf', 1981, pág. 102.

57 Cf. Birgit-Verena Karnapp, «Kirchen. München und Umgebung nach 1945», Munich/Berlin, 1996, pág. 53-55.

58 Asi se titula un escrito editado por él (Freiburg, 1981).

59 Según el monje benedictino Angelus A. Häussling, «Von Sinn der Liturgia», Schriften der Katolischen Akademie in Bayern, 140 (1991), pág. 118-130; aquí 118 .

60 Voz «Liturgia» en: Rupert Berger, «Neues Pastoralliturgiesches Handlexikon», Freiburg, 1999, pág. 309-311; aquí 310.

${ }^{61}$ «Sacrosanctum Concilium», art. 7 y 10 .

${ }^{62}$ Cf. Walter Zahner, «Maison de Dieu Maison, de l'homme», Techniques \& architecture, 459 (2002), pág. 68-75; aqui 68.

${ }^{63}$ Editado por el Secretariado de la Conferencia Episcopal Alemana, Bonn, 2003

${ }^{64}$ Ibidem, pág. 14.

${ }^{65}$ Cf. el catálogo de la exposición: Walter Zahner (ed.), «Schätze! Kirchen des 20. Jahrhunderts», Lautertal, 2007 (con algunos artículos importantes, entre otros, de Albert Gerhards o Maria Schwarz).

${ }_{66}$ Citado según Meinrad Franz, «Zur Geschichte von St. Judas Thaddäus», en: Sa., «Katholisches Gemeindezentrum St. Judas Thaddäus, Karlsruhe-Neuret», Lindenberg, 1998, pág. I ss.; aquí 2.

${ }^{67}$ Cf. Walter Zahner, "Katholisches Gemeindezentrum St. Judas Thaddäus, Karlsruhe-Neureut», en: Conrad Lienhardt (ed.), "Ottokar Uhl. Werk, Theorie, Prespektiven», Regensburg, 2000, pág. 115-136; y Thomas Maymann, «Architektonische Planung: Partizipation und Reduktion. Ottokar Uhl und der Kirchenbau St. Judas Thaddäus in Karlsruhe», en: Nadine Baumann/Martin Stuflesser (eds.), «Das Geheimnis lasst uns künden. Liturgie zwischen Wissenschaft und pastoraler Wirklichkeit», Münster, 2005, pág. 197-209.

${ }_{68}$ Cf. Gerhardt Hueck, «Der Neubau der Herz-Jesu-Kirche in München» (Tesis académica), München, 1998; está prevista su publicación; Meinhard von Gerkan, «Herz-Jesu-Kirche in München», Baumeister, 2/2001 (2001), pág. 44-54; y Monika Römisch, «Kath. Pfarrkirche Herz-Jesu München-Neuhausen», Lindenberg, 2002.

${ }^{69}$ Cf. Wilhelm Kücker, «Pfarrzentrum St. Franziskus, Regensburg», en: Ingeborg Flagge y otros (eds.), «DAM Jahrbuch 2003», Munich, 2003, pág. 66-75; y Walter Zahner, «Eglise Saint-Francois, Ratisbonne-Burgweinting, Allemagne», L'architecture d'aujourd'hui, 356 (2005), pág. 70-75

${ }^{70}$ Cf. «Das Pontifikale zur Altarweihe, hier zitiert nach Stichwort: Altar», en: Rupert Berger, «Neues Pastoralliturgisches Handlexikon», Freiburg, 1999, pág. 15-18; aquí 17.

71 Cf. «Sacrosanctum Concilium», art. 7.

72 Cf. más extensamente: Albert Gerhards/Thomas Sternberg/Walter Zahner (eds.), «Communio-Räume. Auf der suche nach der angemessenen raumgestalt katholischer liturgie», Regensburg, 2003

73 Cf. Albert Gerhards, «In der Mitte der Versammlung», Trier, 2001.

74 Cf. Johannes Krämer/Walter Zahner, «Realizzazioni di spazi liturgici in Germania. Analisi liturgicae architettonica», en: Goffredo Boselli (ed.) «Spazio liturgico e orientamento» (Atti del IV Convegno Liturgico Internazionale, Bose 1-3 giugno 2006), Bose, 2007, pág. 61-83.

${ }^{75}$ Cf. Goffredo Boselli (ed.), «L'ambone: tavola della parola di Dio» (Atti del III Convegno liturgico internazionale, Bose 2-4 giugno 2005), Bose, 2006; Walter Zahner, «Ästhetik und Diakonie: der Ort des Wortes als Initiationsort diakonischen Handelns», en: Benedikt Kranemann/Thomas Sternberg/Walter Zahner (eds.), «Die diakonale Dimension der Liturgie». Freiburg, 2006, pág. 261-270.

76 Cf. Rudolf Schwarz, «Kirchenbau», cit., pág. 147-154.

77 Rudolf Schwarz, «Vom Bau der Kirche», cit., pág. 94.

78 «Zitiert nach Lutz Schultz. Dem Glauben Raum geben: Erfahrungen eines Gemeindeweges», en: «Communio-Räume», cit., pág. 197-199; aquí 198.

79 Cf. Walter Zahner, «Maria Magdalena. Katholische und evangelische Kirche in Freiburg-Rieselfeld», Lindenberg, 2006; otras referencias literarias se pueden ver en: Matthias Ludwig y Reinhard Mawick (eds.), «Gottes neue Häuser. Kirchenbau des 21. Jahrhunderts in Deutschland», Frankfurt-am-Main, 2007, pág. 124-129.

${ }^{80}$ Cf. Christin Feireiss, «Vorwort» en: Christin Feireiss y Hans-Jürgen Commerell (eds.), «Kister Scheithauer Gross. Doppelkirche für zwei Konfessionen», Berlín, 2004, pág. 4

${ }^{81}$ Cf. Burkhard Cramer, «Der offene Ring. Erfahrungen bei einer Eucharistiefeier auf Burg Rothenfels», Gottesdienst, 40 (2006), pág. 20 ss.; aqui 20.

82 Cf. Walter Zahner, «Liturgie zwischen Geist und Form», en: Conrad Lienhardt, «Sakralraum im Umbruch. Kirchenbau der Katholischen Kirche in Oberösterreich seit 1948», Regensburg, 2004, pág. 18 